\title{
اثر المعرفة السوقية في تحسين الاداء التسويقي -دراسة تطبيقية في شركات الاتصال للهاتف المعمول في العراق
}

كلية الإدارة والاقتّاد عبد الواحد الثويلي المستصرية
أ. م. د. سعدون حمود جثير الربيعاوي

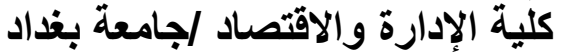

تهدف الاراسة الى تحديد مدى المعرفة السوقية في الثركات المبحوثة ،وفيما لو كاتت المعرفة

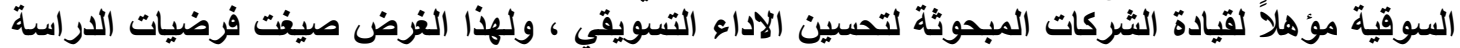

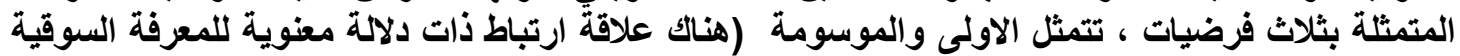

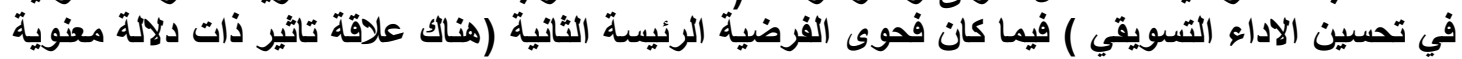

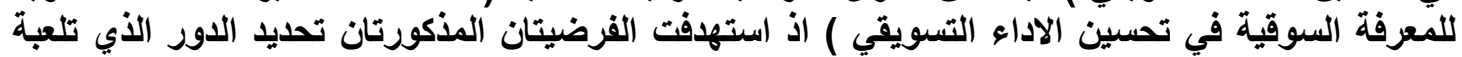

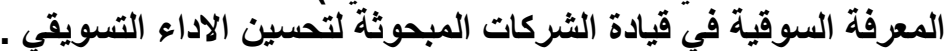

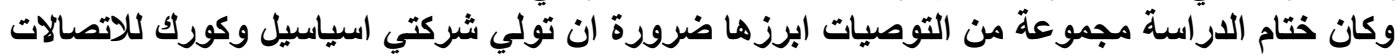

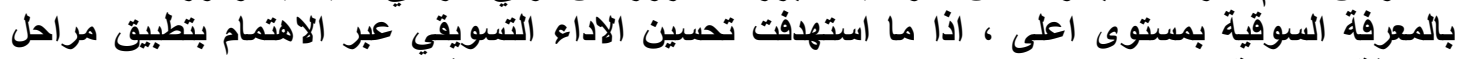

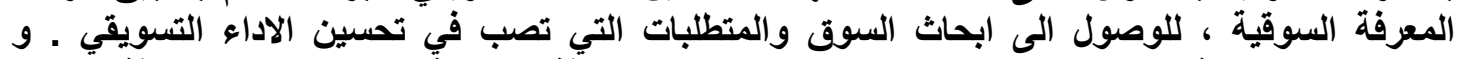

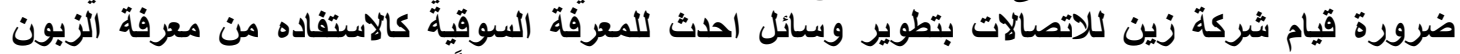

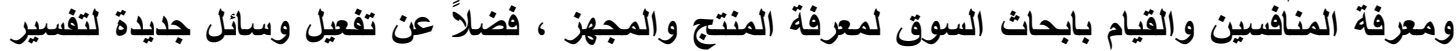

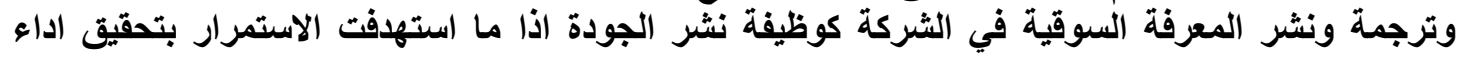

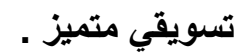

الامطامات الرئيسية للبمث/ المعرفة السوقيةـ الاداء التسويقي .

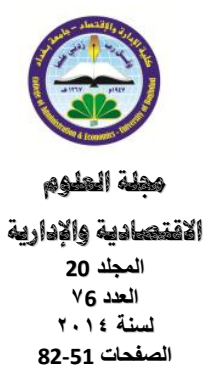

ملاحظة/ البحث مستل من رسالة ماجستير 


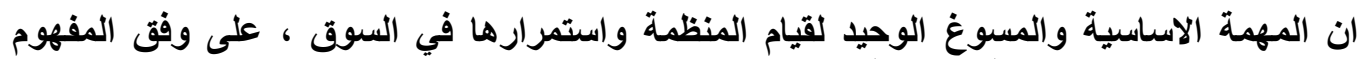

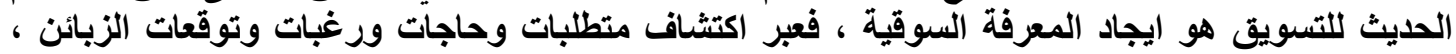

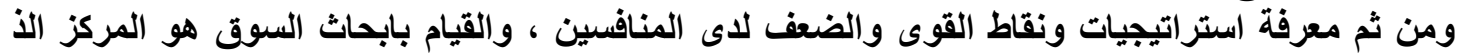

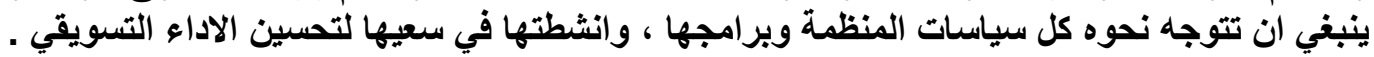

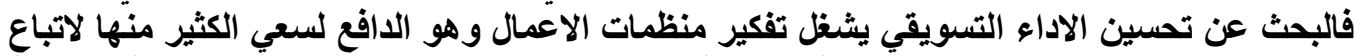

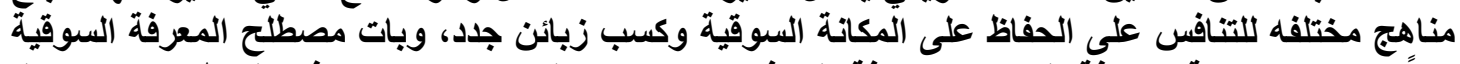

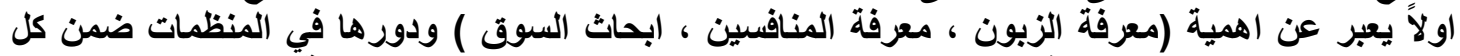

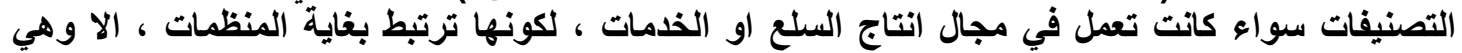

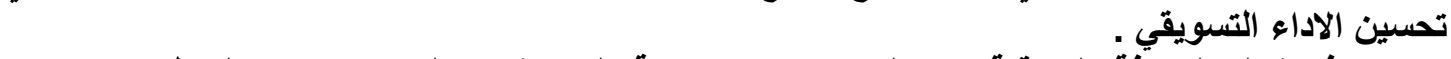

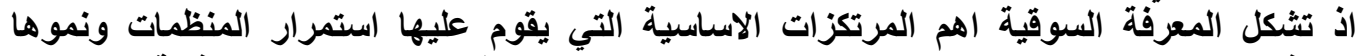

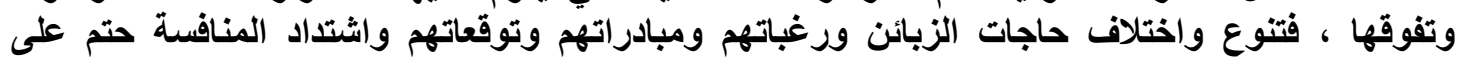

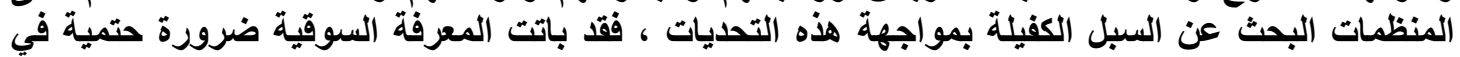

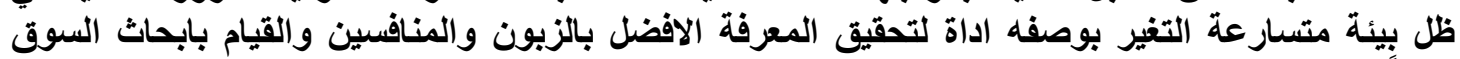

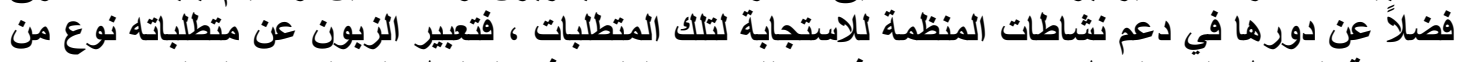

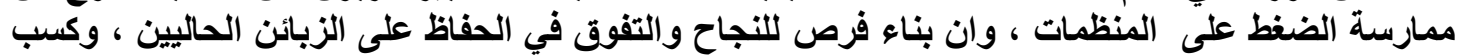

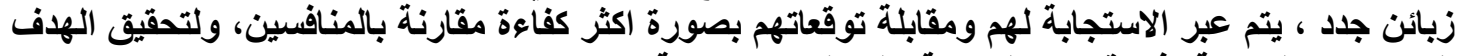

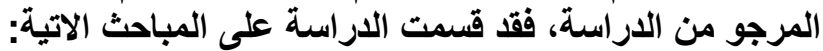

$$
\text { المبحث الاول: منهجية البحث. }
$$

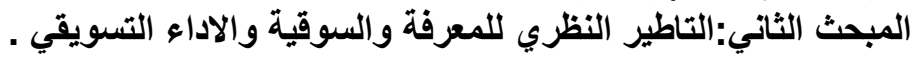

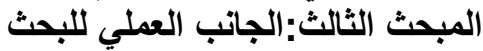

المبحث الرابع: الاستنتاجات والتوصي التوصيات

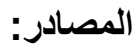




\section{المبحث الاول/ هنهبية الدراسة}

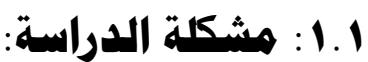

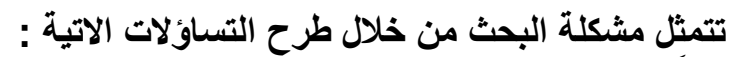

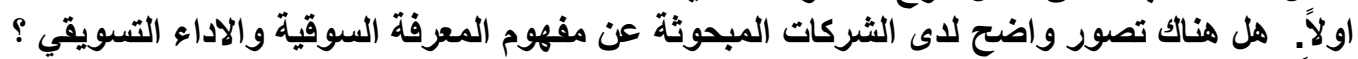

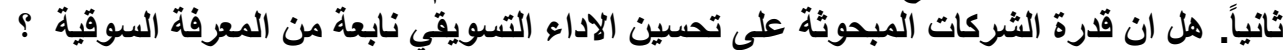

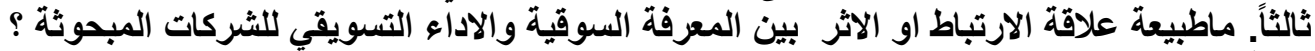
رابعاً. هل هناك تفاوت في اجابات المبحوثين عن الائر المعرفة السوقية والائة والاداء التسويقي ؟

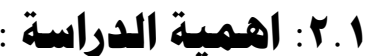

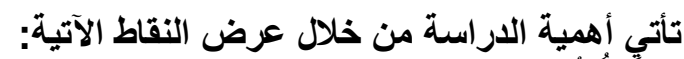

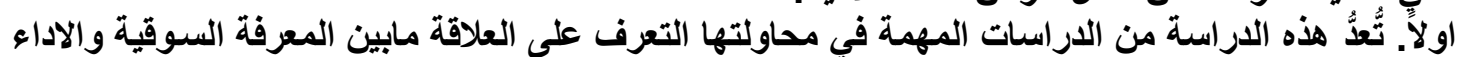

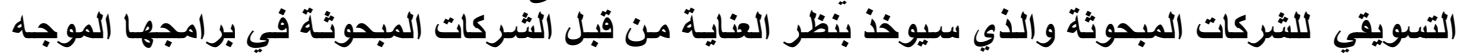
نحو الزبوني ونحو المنافئن المبحون.

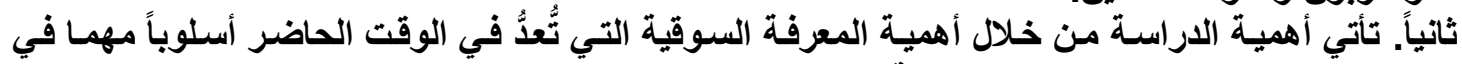

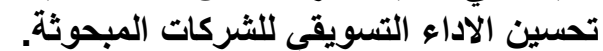

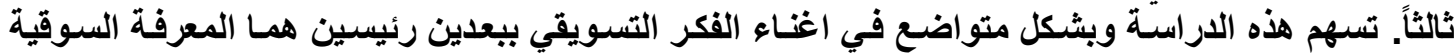
والاداء التسويقي.

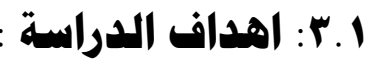 \\ تهذف الدراسة الى تحقيق الاتي :} اولاً. تقليم معالم نظرية وميدانية للثركات المبحوثة عن الدور الذي تلعبه المعرفة السوقية في تحسين الاداء

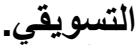
ثنانياً. التعرف على طبيعة العلاقة بين المعرفة السوقية في الثركات المبحوثة والاداء والتسويقي .

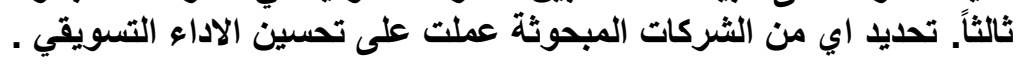

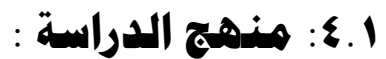

اعتمدت الدراسة الاسلوب الاستطلاعي التحليلي، فضلاً عن استخدام المنهج الوصفي في عرض بيانات الدراسة وتحيلها للوصول الى النتائج .

\subsection{1 : حدود الدراسة :}

اولاً. الحدود المكانيـة : تم تطبيق الجاتب العملي من الدراسـة في عدد من شركات الهاتف المحمول في العراق كل من (زين، اسياسيل، كورك).

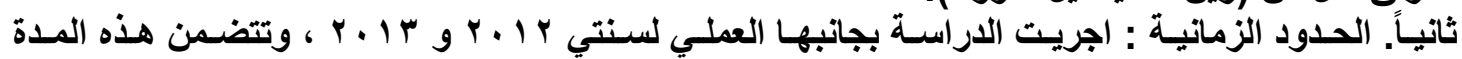

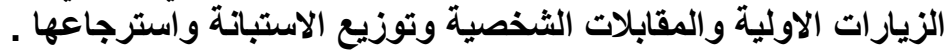




\section{1: اختبار صدق وثبات مقياس الدراسة :}

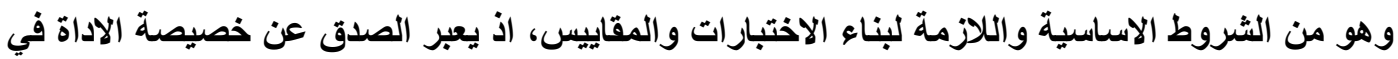

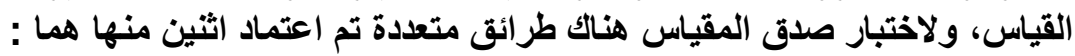

اولاً. الصدق الظاهري : افضل وسيلة للتاكد من الصدق الظاهري لاداة القياس قيام عدد من الخبراء

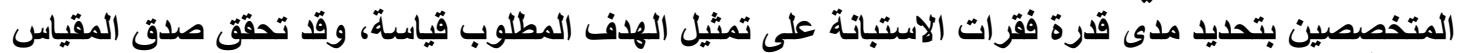

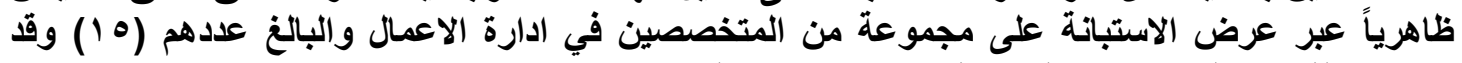

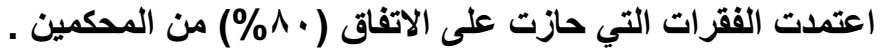

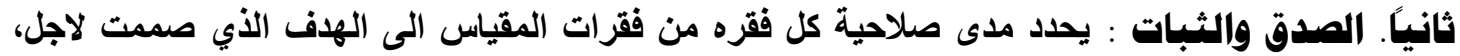

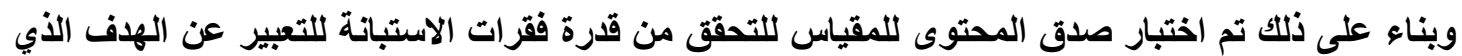

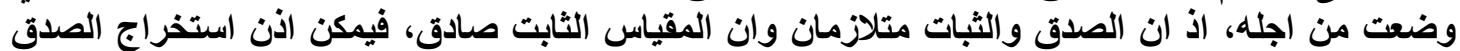

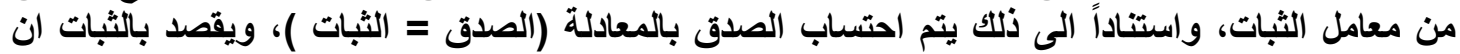

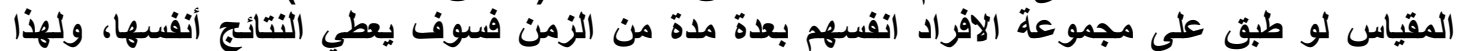

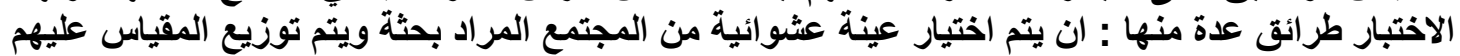

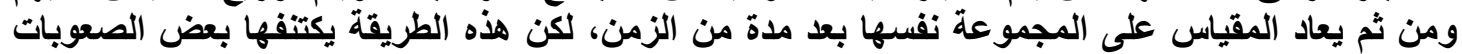

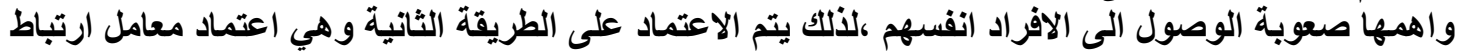

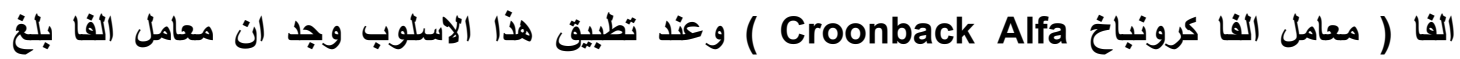
(0.976) وهذا يعني انها ذات ثبات عال ـ وبعد ان وجد الثبات يمكن الان ايجاد الصدق وفق الصيغة المذكورة انفاً وبعد اجراء العمليات الحسابية تبين ان صدق المقياس يبلغ (0.983) وهي قيمة عالية تلدل

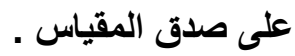

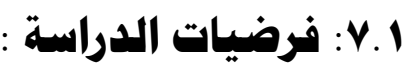

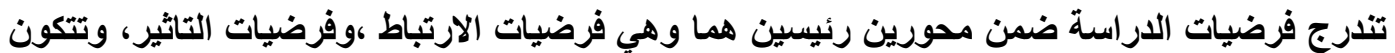

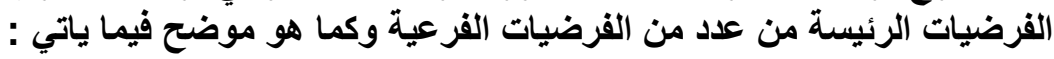

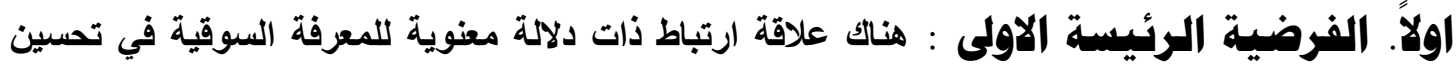

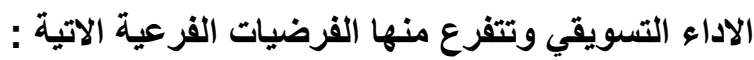

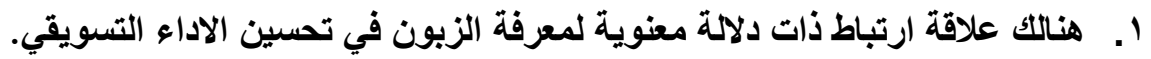

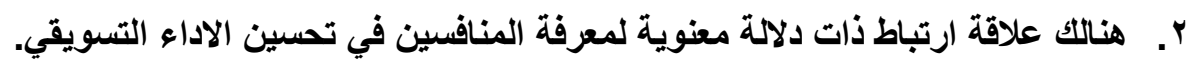

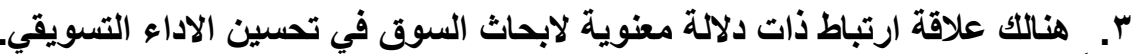

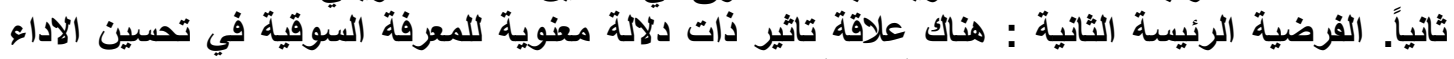

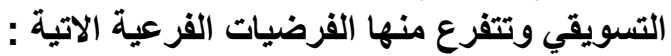

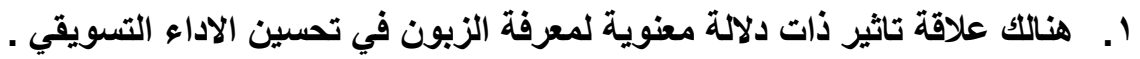

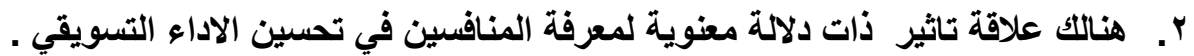

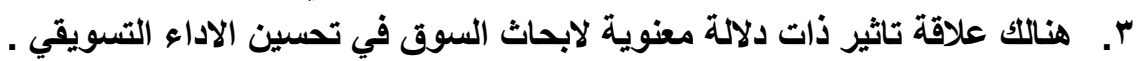




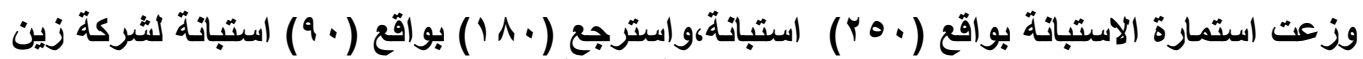

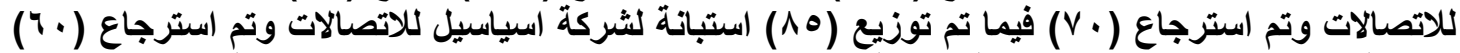

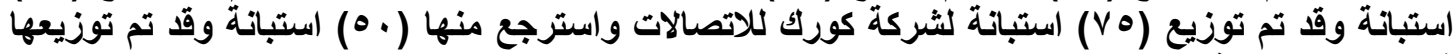
تم جمع المطلومات عبر الملاحظة والمقابلات الثخصية والجدول (1) يوضح خصائص عينة الدارسة

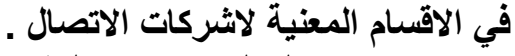
جدول (1)

خصائص عينة (لاراسة (1)

\begin{tabular}{|c|c|c|c|c|c|c|c|c|}
\hline \multicolumn{2}{|c|}{ شركة كورك } & \multicolumn{2}{|c|}{ شركة اسياسيل } & \multicolumn{2}{|c|}{ شركة زين } & \multirow{2}{*}{ الفئة } & \multirow{2}{*}{ المطلومات } & \multirow{2}{*}{$ت$} \\
\hline النسبة & العدد & النسبة & العدد & النسبة & | العدد & & & \\
\hline $7 \leqslant .0$ & rr & $\because$. & r & $00 . V$ & rq & 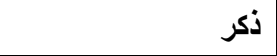 & \multirow{2}{*}{ النوع الاجتماعي } & \multirow{2}{*}{1} \\
\hline r6.0 & 11 & $\varepsilon \cdot$. & $r \varepsilon$ & \& & r & انثى & & \\
\hline $1 \ldots$. & 0. & $1 \ldots$ & 7. & $1 \ldots$. & $v$. & \multicolumn{2}{|c|}{ المجموع } & \\
\hline 24.0 & ir & ir.r & $\wedge$ & $1 .$. & v & $25-20$ & \multirow{4}{*}{ العمر - العم } & \multirow{4}{*}{2} \\
\hline 50.0 & ro & Or.r & rr & $0 .$. & ro & $30-26$ & & \\
\hline 24.0 & Ir & r..V & 17 & rr.q & 17 & 35-31 & & \\
\hline r.. & 1 & $7 . \mathrm{V}$ & $\varepsilon$ & $\mid v .1$ & ir & $40-36$ & & \\
\hline $1 \ldots$ & o. & $1 \ldots$ & 7. & $1 \cdots$ & v. & \multicolumn{2}{|c|}{ المجموع } & \\
\hline$\cdots$ & . & $\cdots$ & . & $\cdots$. & . & ابتدائية & \multirow{6}{*}{ المؤهل العلمي } & \multirow{6}{*}{3} \\
\hline$\cdots$ & . & $\cdots$ & . & $\ldots$. & . & متوسطة & & \\
\hline 22.0 & 11 & $\Lambda . r$ & ○ & r.q & r & اعدادية & & \\
\hline 12.0 & 7 & $\ldots$ & . & $1 \varepsilon . r$ & 1. & | دبلوم & & \\
\hline 54.0 & $r v$ & vo.. & $\leqslant 0$ & $\because$. & $\leqslant r$ & بكالوريوس & & \\
\hline 12.0 & 7 & $18 . \mathrm{V}$ & 1. & rr.q & 17 & شهادة عليا & & \\
\hline $1 \ldots$. & 0. & $1 \cdots \cdot$ & 7. & $1 \ldots$. & v. & \multicolumn{2}{|c|}{ المجموع } & \\
\hline 82.0 & \& & vo.. & $\leqslant 0$ & $\mathrm{v} \cdot .$. & $\leq 9$ & من • سنوات فما دون & \multirow{2}{*}{ عدد سنوات الخدمة } & \multirow{2}{*}{4} \\
\hline 18.0 & 9 & ro.e. & 10 & $r \cdot . \cdot$ & ri & من 1 الى · 1 سنوات & & \\
\hline $1 \ldots$. & 0 . & $1 \ldots$ & 7. & $1 \ldots$. & v. & \multicolumn{2}{|c|}{ المجموع } & \\
\hline
\end{tabular}




\begin{tabular}{|c|c|c|c|c|c|c|c|c|}
\hline 8.0 & 4 & $11 . v$ & $v$ & $10 . V$ & 11 & موظف قسم التسويق الجغرافي & \multirow{7}{*}{ الغنوان الوظيفي } & \multirow{7}{*}{5} \\
\hline 14.0 & 7 & r..v & 17 & ro.v & 11 & موظف دراسات السوق & & \\
\hline 24.0 & 12 & $r \cdot . \cdot$ & ir & 11.8 & $\wedge$ & موظف خدمة الزبون & & \\
\hline 24.0 & 12 & $r \cdot . \cdot$ & ir & $10 . V$ & 11 & موظف الذكاء التنافسي & & \\
\hline 8.0 & 4 & $1 \cdot$. & 8 & $1 \leqslant . r$ & 1. & رئيس فريق & & \\
\hline 8.0 & 4 & 0. & $r$ & $\varepsilon . r$ & $r$ & مشرف اقليمي & & \\
\hline 14.0 & 7 & ד.V & $\varepsilon$ & ir.q & 9 & 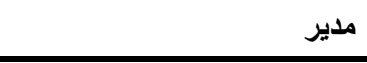 & & \\
\hline 100.0 & 50 & $1 \ldots$. & 7. & $1 \ldots$ & $v \cdot$ & \multicolumn{3}{|c|}{ المجموع } \\
\hline $\mathbf{0}$ & $\mathbf{0}$ & $\cdots$ &. & $1 . \varepsilon$ & 1 & من ا سنوات فما دون & \multirow{5}{*}{ فد سنوات الخدمة } & \multirow{5}{*}{6} \\
\hline 70.0 & 35 & $\because$. & mi & $0 .$. & ro & من ץ الى ب سنوات & & \\
\hline 12.0 & 6 & ro.e & $r$ & YN. & r. & من ع الى • سنوات & & \\
\hline 18.0 & 9 & $0 .$. & $r$ & $r \cdot . \cdot$ & $1 \varepsilon$ & اكثر من • & & \\
\hline 100.0 & 50 & $1 \cdots \cdot$ & 9. & $1 \ldots$. & $v \cdot$ & المجموع & & \\
\hline
\end{tabular}

\section{المبمث الثاني/ التاطير النظري للمعرفة السوقية والأداء التسويقي}

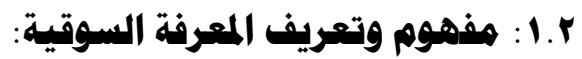

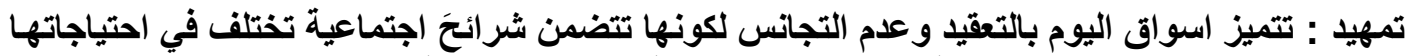

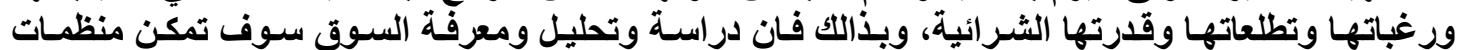

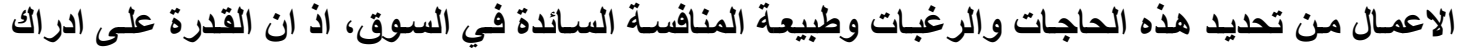

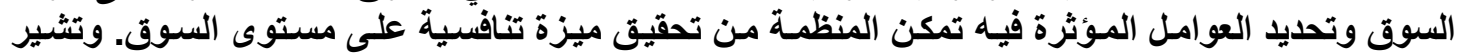

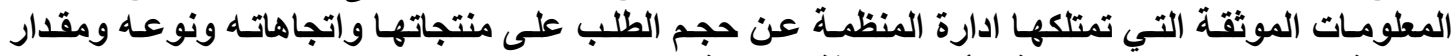

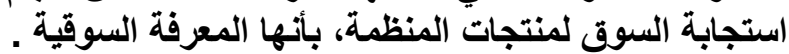

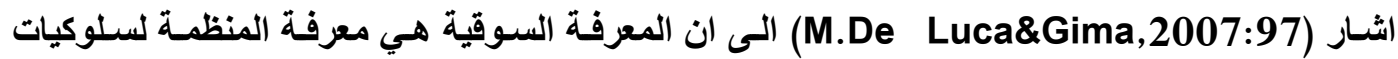

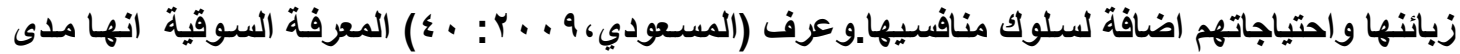

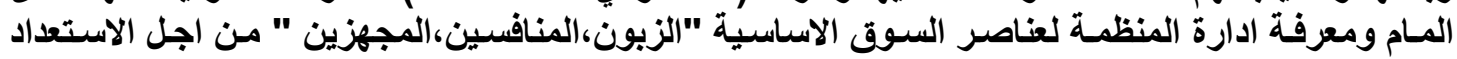

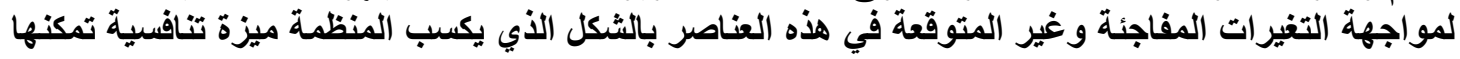

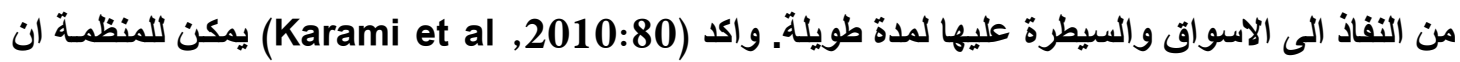

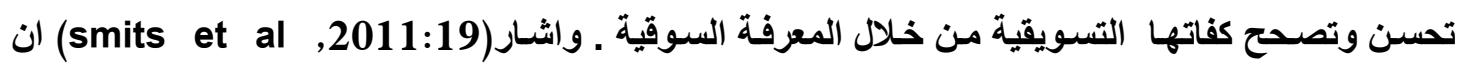

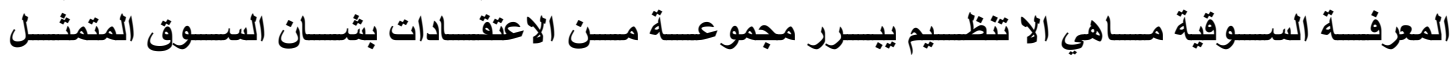

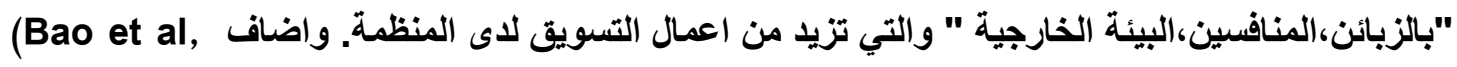
(312: 2012 ان المعرفة السوقية تتعلق بوجود تكنلوجي تخلق منتوجـات جديدة وتبنـي ادخـال النجاح على التى

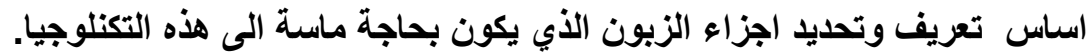

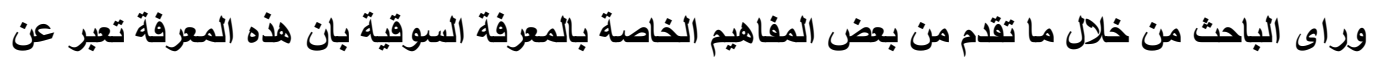

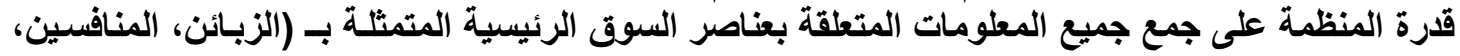




\section{شركات الاتصال للهاتف المحمول في العراق}

ابحاث السوق) وتحليلها وتفسيرها بالشكل الذي يعززمن موقعها التنافسي ويزيد من حصتها السوقية ويمكنها من التنبوء بحجم الطلب على منتجاتها.

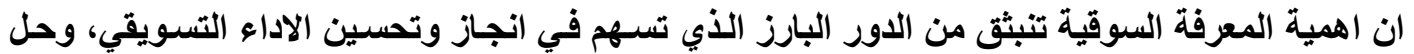

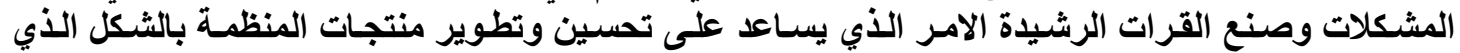

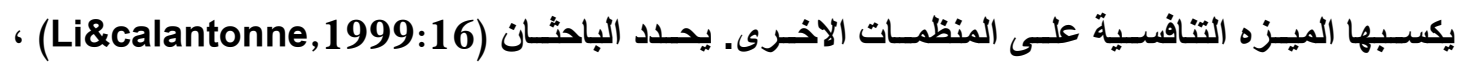

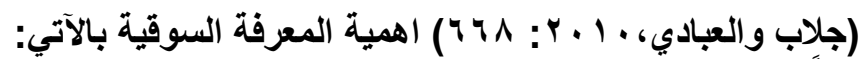

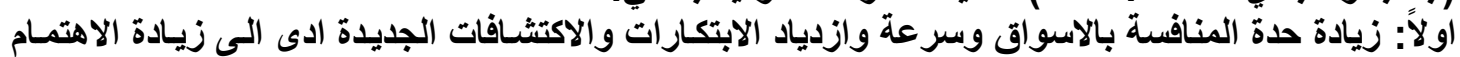

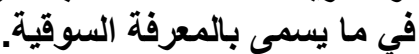

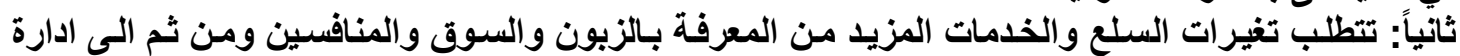
معرفة قوية.

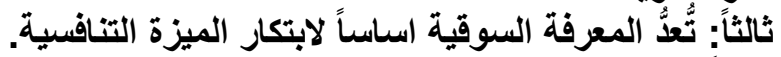

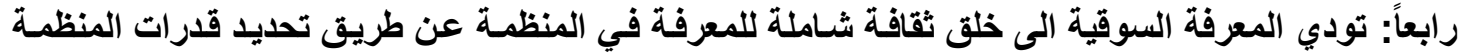
وحاجتها المستثبلية.

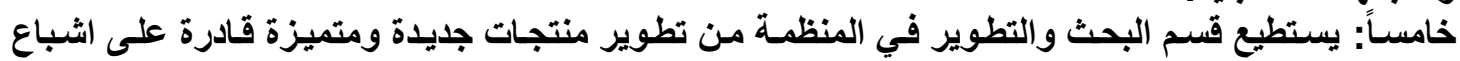
حاجات ورغبات الزبائن. سادساً: تمكن المعرفة الزبات السوقية ادارة المنظمة من اتخاذ القرارات المناسبة.

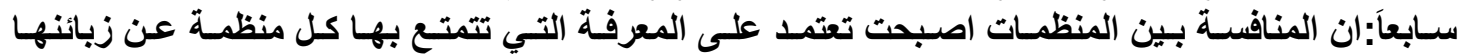
ومنافسيها.

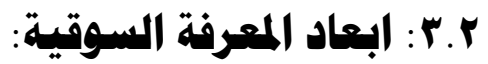

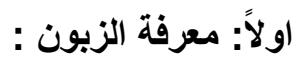

اشار ( Roy \& Starropoulos,2007:15) ان معرفة الزبون ضمن التسويق تمثل مصدرا مهمـا

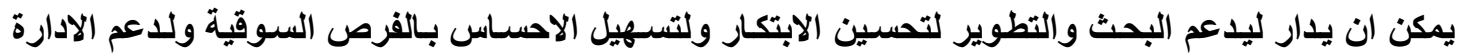

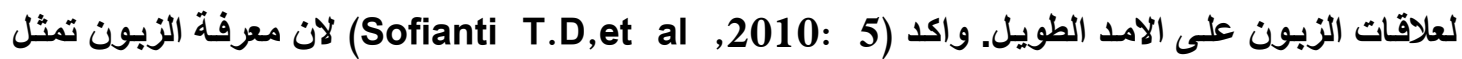

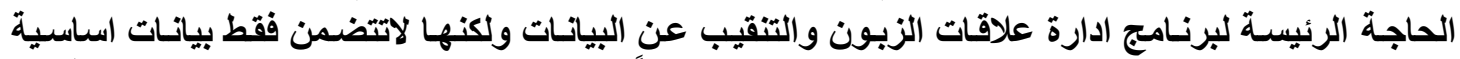

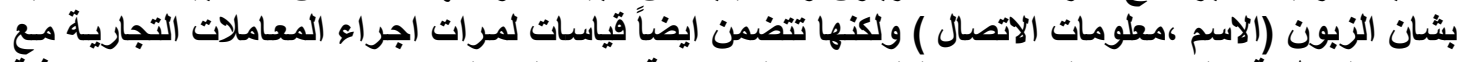

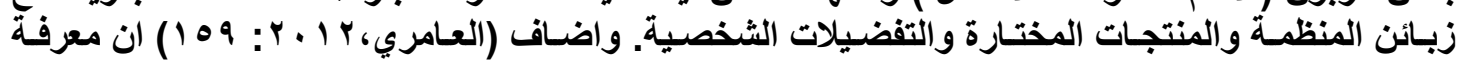

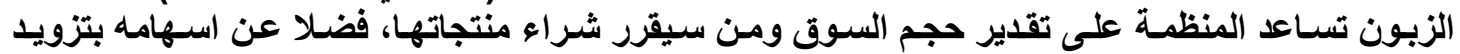

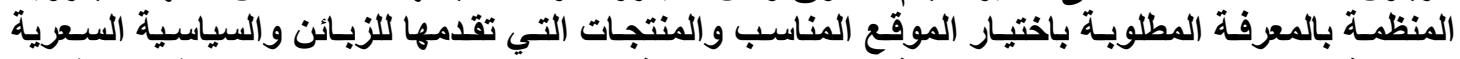

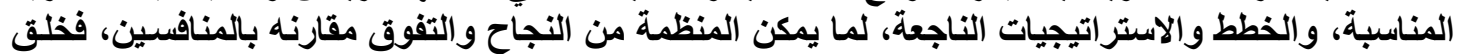

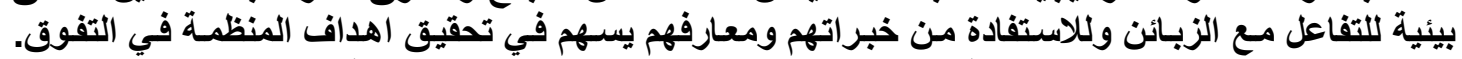

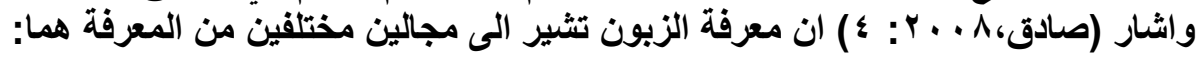




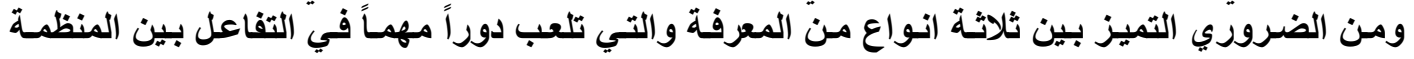

والزبائن وهي الاتي : (Alhawari et al 2008:175) .

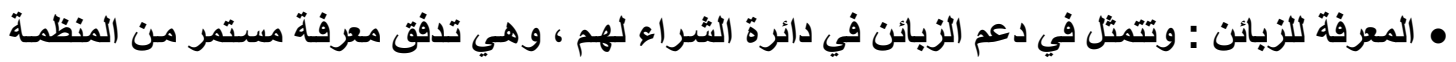
الى زبائنها . • المعرفة من الزبائن : ترد من قبل المنظمة لابتكار المنتجات ولتوليد الافكار اضافة الى التحسين المتواصل • المعرفة بشـان الزبون : تجمع في خدمـة ادارة علاقـات الزبون وتدعم العمليـات وتحلل في عملية تحليل

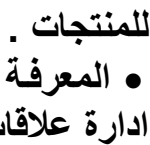

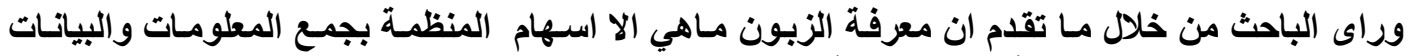

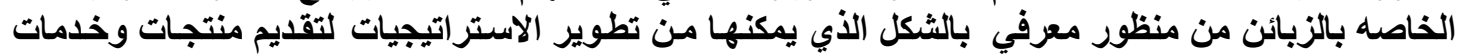

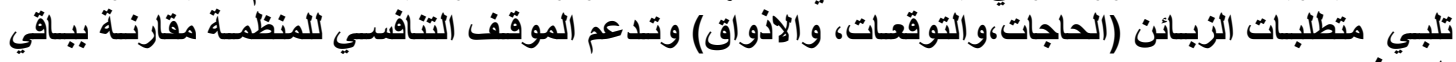
المتنافسين.

\section{ثانياً: همعرفة المنافسين ا ـ مفهوم معرفة المنافسين} اشار(Jarvis, 2007:60) الى ان على المنظمـات اخذ وقت كافي لمعرفة معلومـات عن المنافسين

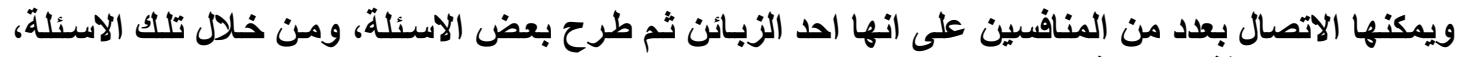

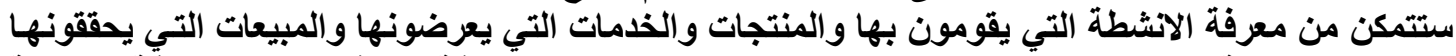

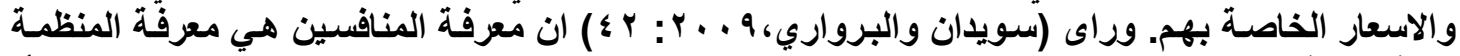

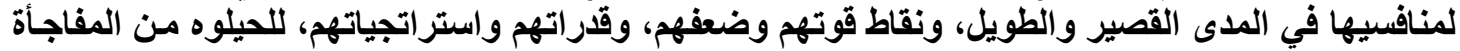

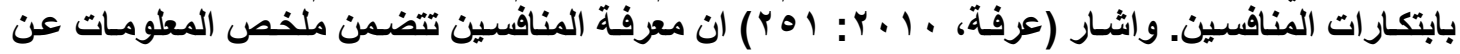

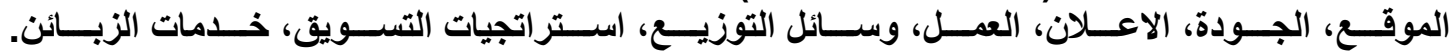

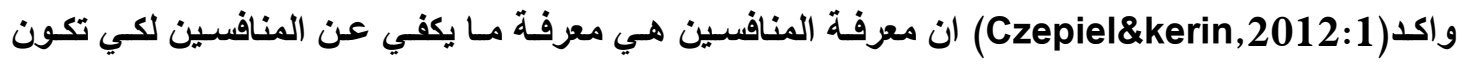

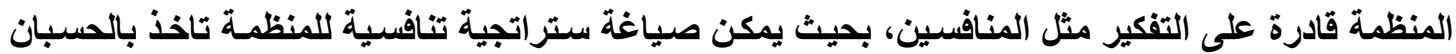

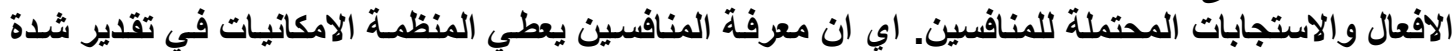

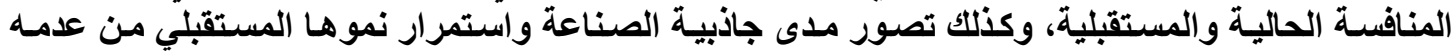

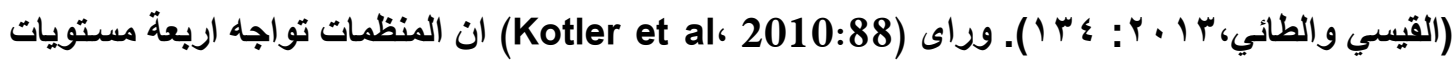
من المنافسين وهي كالاتي : المئي

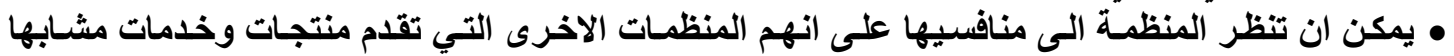

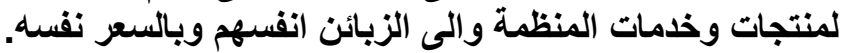

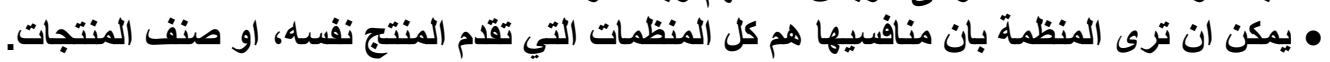

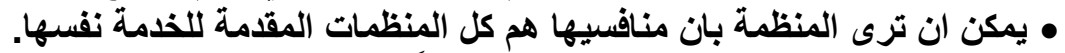

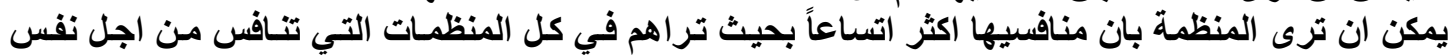
دولارات الزبون. 


\section{شركات الاتصال للهاتف المحمول في العراق}

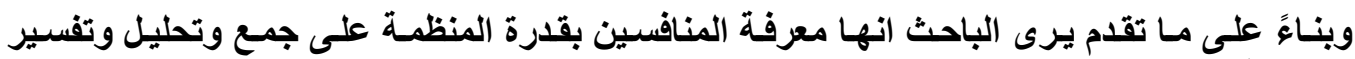

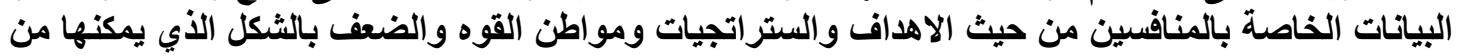

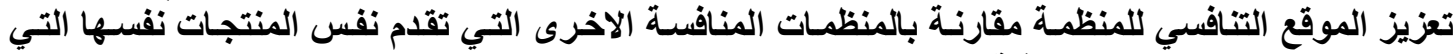
تستهدف نفس الاسواق ولنفس فئة الزبائن. r أنواع المنافسين حدد كل من (Kotler,1997:230-240) و (Pride\&Ferrell, 2000:57-58) اربعة انـواع من

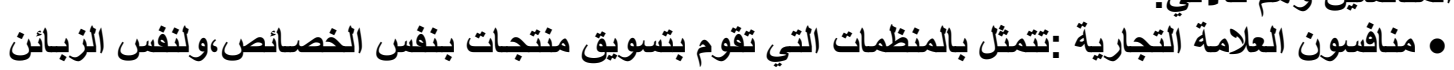

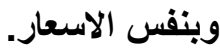
• منافسوا المنتج : تشمل المنظمـات التي تتنـافس في نفس المنتج ونفس الصف ولكن بخصسائص مختلفة و اسعار مختلفة. • المنافسين العـامين : تمثل المنظمسات التي تقوم ببيع منتجـات مختلفة بصورة كبيرة والتي تستخدم لحل

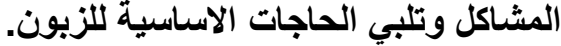
• منافسون الموازنة الكلية : بقية المنظمات التية التي تتنافس على الموارد المالية المحدودة لنفس الزبائن.

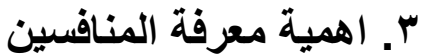

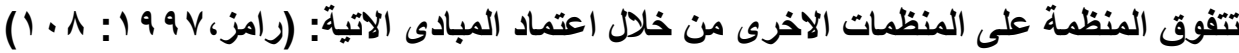

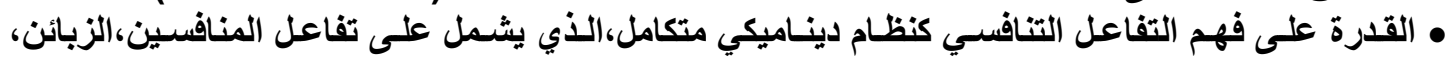

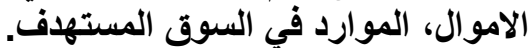
• القدرة على استخدام ذلك القهم للتنبؤ بنتائج تاثير معين ذلك النظام وكيفية استحداث نمط جديد من التوازن المستقز في النظام المعني. • وفرة الموارد غير المستثمرة التي قد توجة المئى استعمالات واغراض مختلفة في الوقت الحاضر من اجل حصول المنظمة على فوائد مستقبلية.

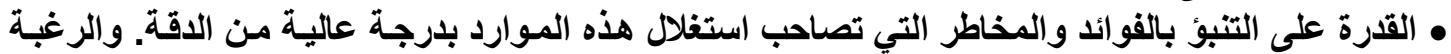
على استغلال الموارد المالية. ثالثًا: ابحاث السوق السنال

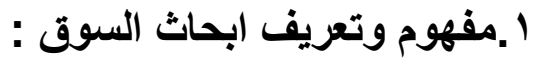

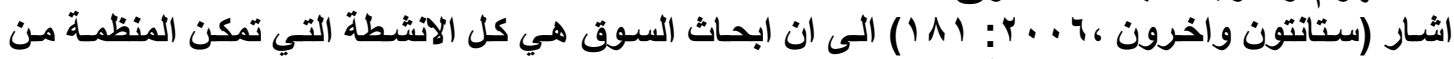

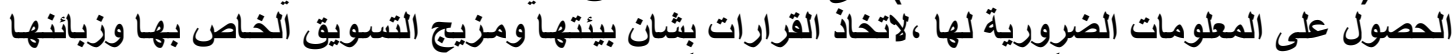

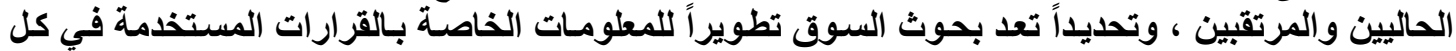

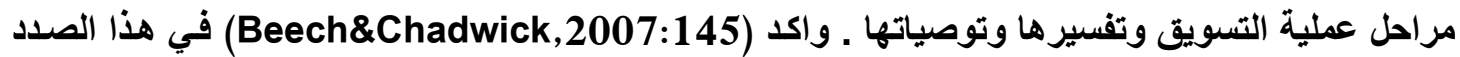

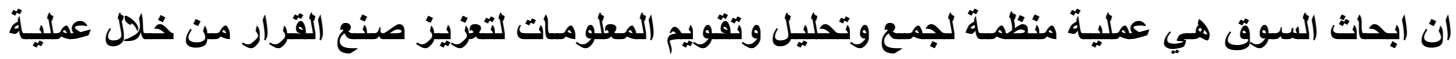

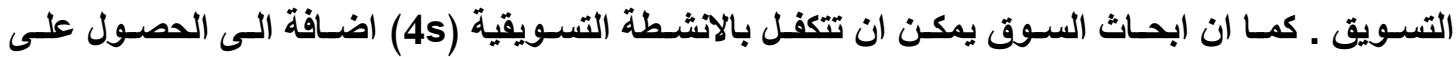

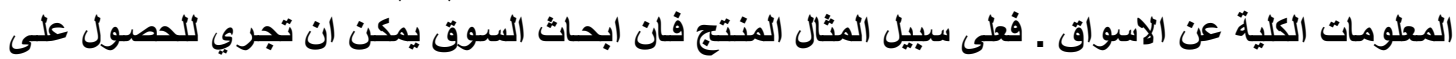

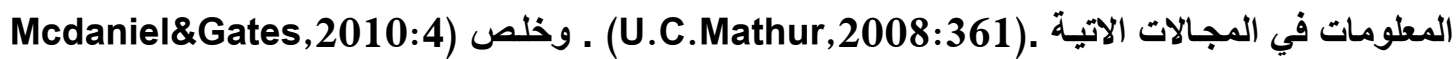

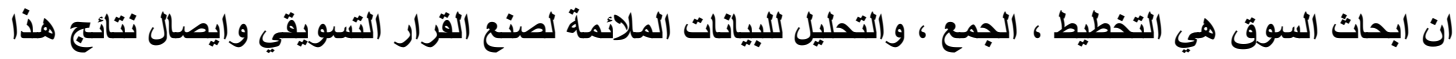

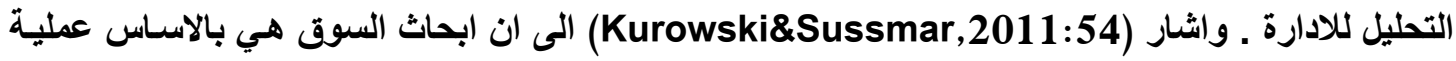

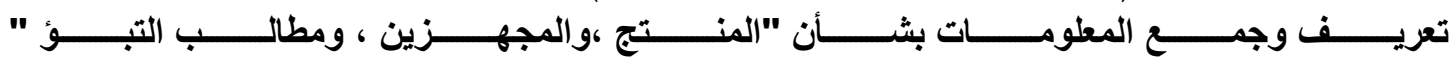

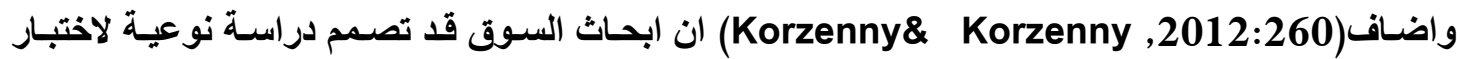

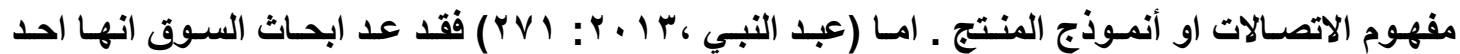

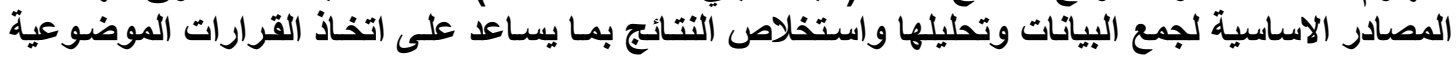




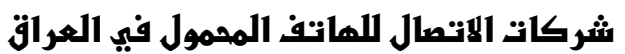

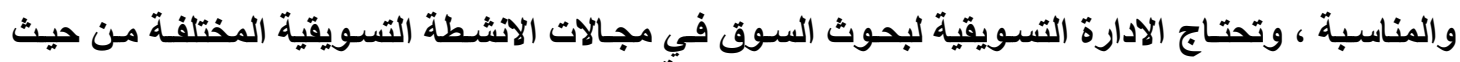

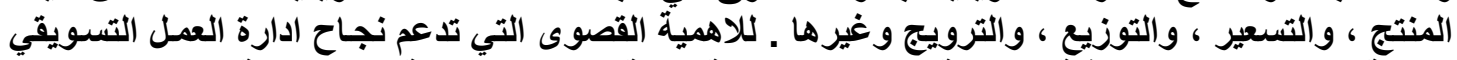

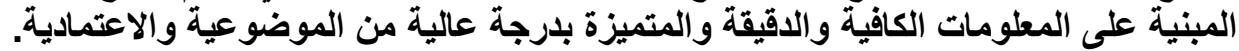

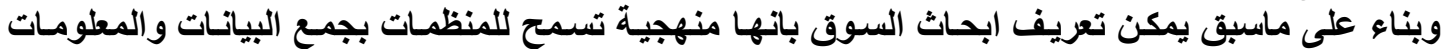

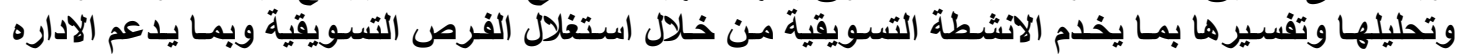

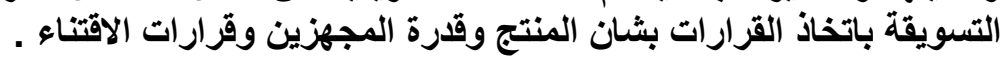

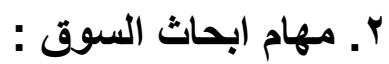

ان المدى الأي تستخدم معه المنظمة البحث السوقي متنوع وواسع . وفي ادناه سنذكر المجالات

الرئيسية التي يتم فيها اجراء البحث السوقي . (64-62 : (G.Bingham\&Gomes,2001) . أـامكانيات السوق : اذ يتوجب على البحث توضيح المبيعات الكلية الاعلى واحتماليات الربح لفرئ لفرص سوق

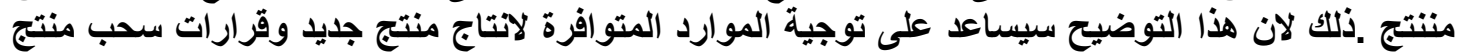

ب- تحليل الحصة السوقية :حيث سينسب الى البحث السوقي مهمة تحليد نسبة ارباح مبيعات المنظمة الى الى العي

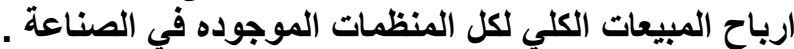

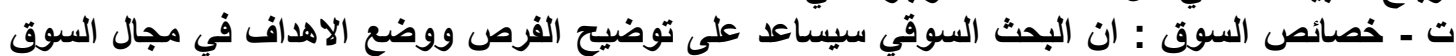

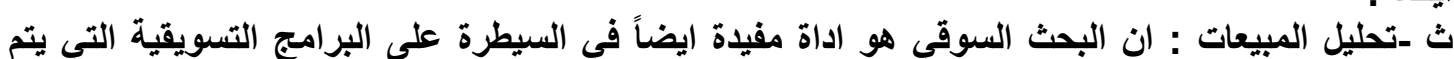

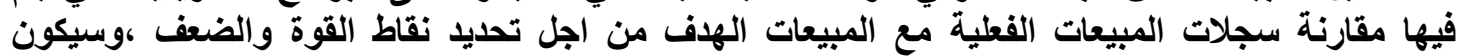

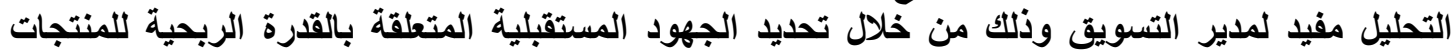

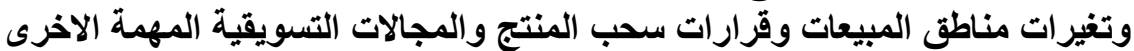

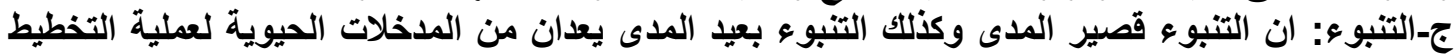

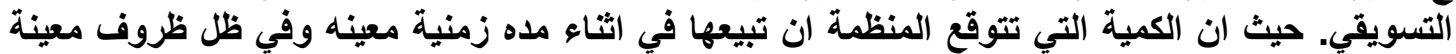

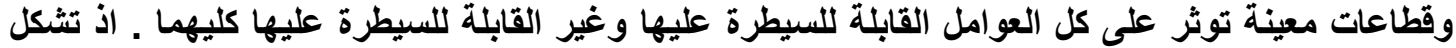

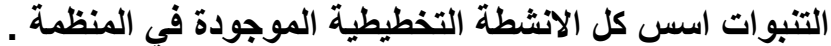

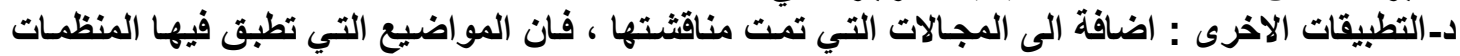

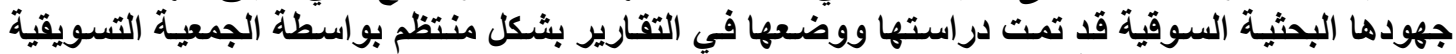

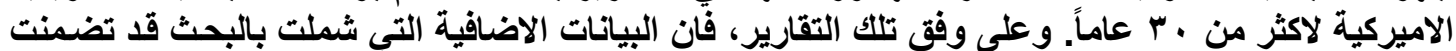

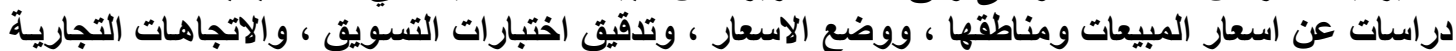

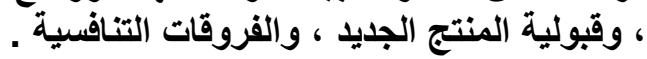




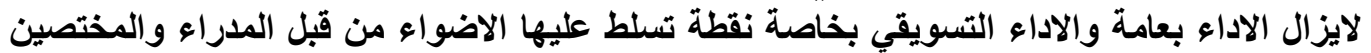

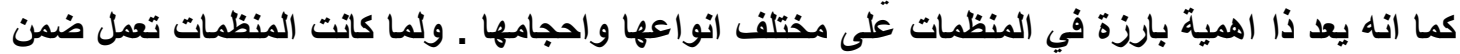

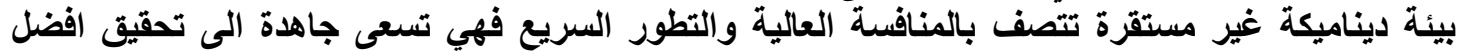

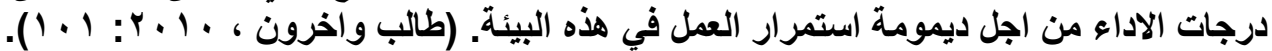

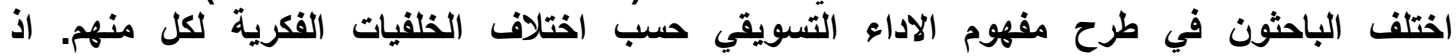

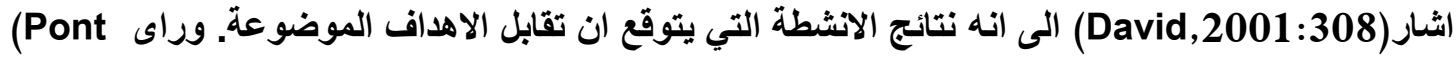

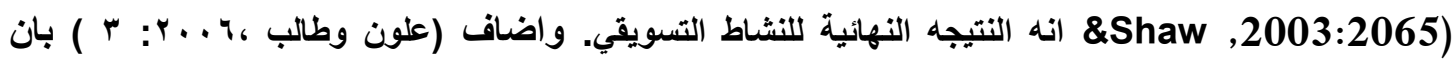

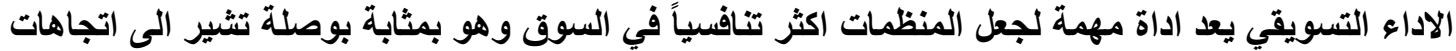

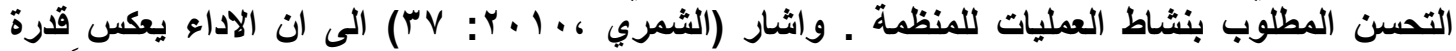

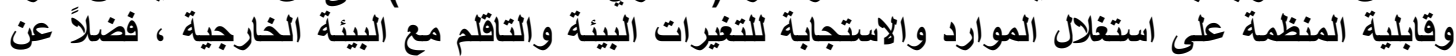

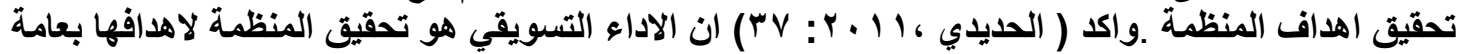

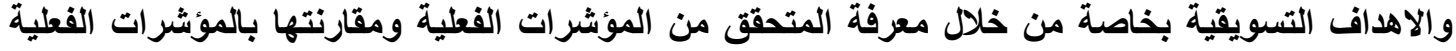

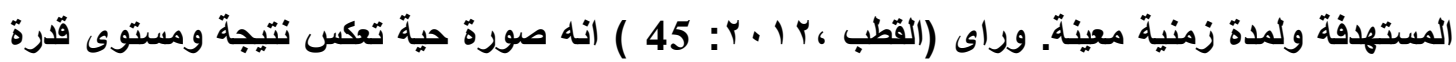

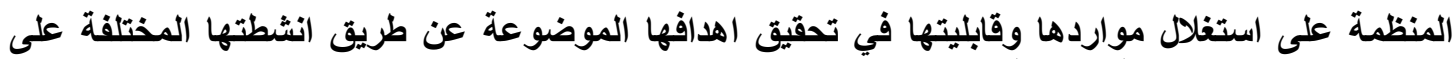
وفق معايير تلائم المنظمة وطبيعة عملها.

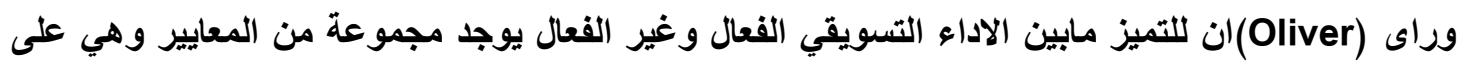

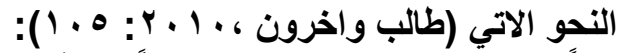

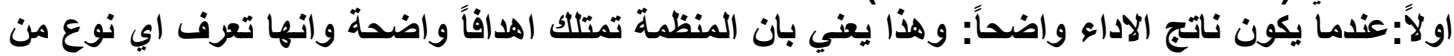

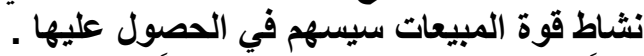

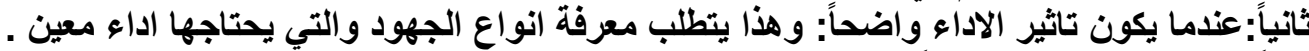

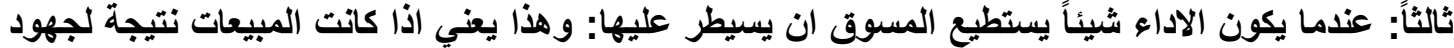

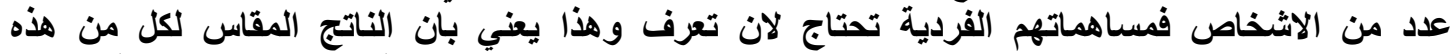

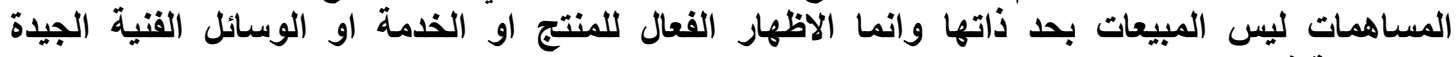

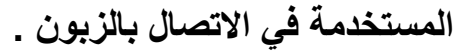

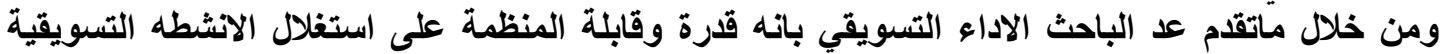
وبما يتلائم وتحقيق الاهداف الموضوعة عن طريق هذه الانثطة على وفق معايير تلانم المنظمة وطبيعة عملها .

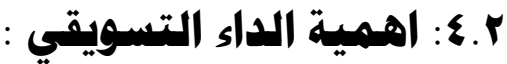

اشار (Daivd,2001:30) ان تحديد الهمية الاداء التسويقي تكمن بالاتي : اولاً: التعرف على مقدار ما انجز من اهداف المنظمة . ثانيًا: توفير المطومات لمختلف المستويات الادارية لاغراض التخطيط والرقابة واتخاذ القرارات المستتدة

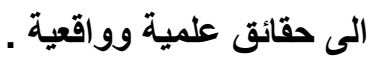

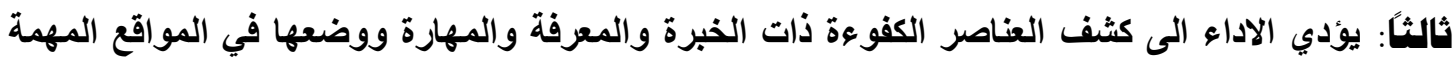

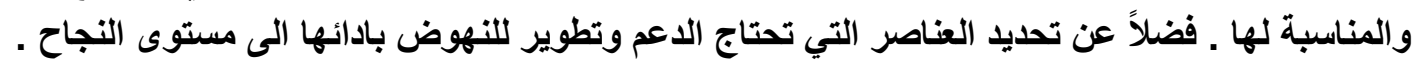

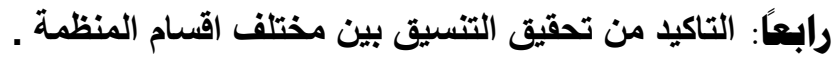

خاهسًا: تثخيص الاخطاء والتفضيلات الحرجة في العملية واتخاذ الخطوات اللازمة لمعالجتها والاهتمام بها. سادساً: يساعد على تحقيق الثمولية والعقلانية في عمليتي التخطيط واتخاذ القرار . 
سابعًا: تساعد المراجعة التسويقية المستمرة على اجراء التحسينات المستمرة في الاداء التسويقي.

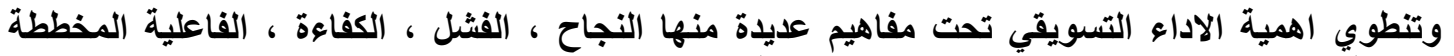

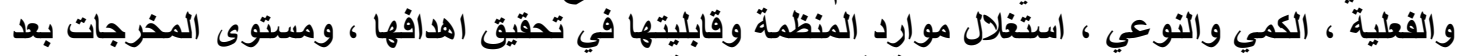

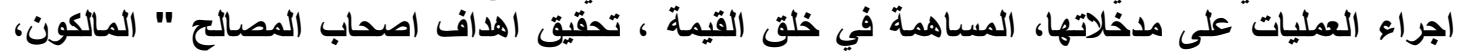

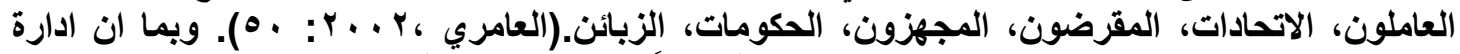

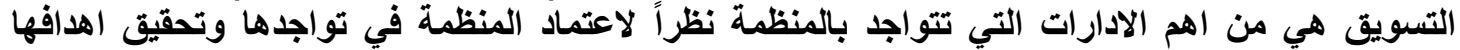

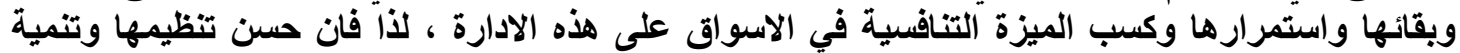

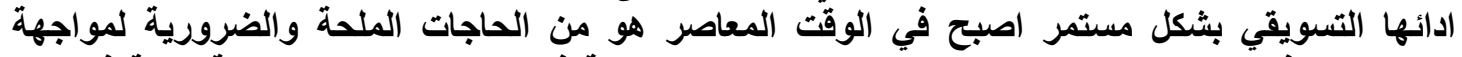

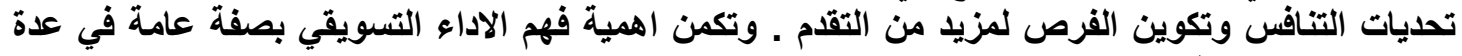

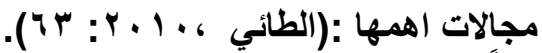

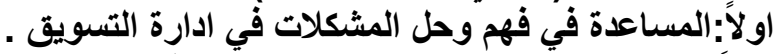

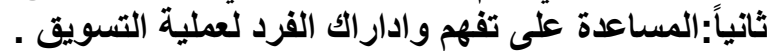

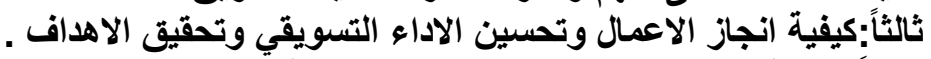

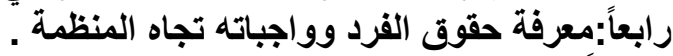

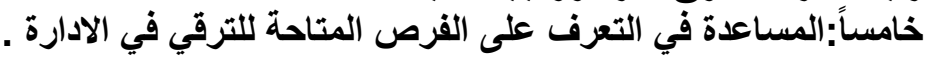
(0.r) هؤشرات قياس الاداء التسويقي:

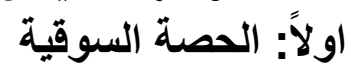

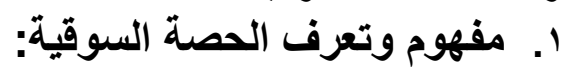

اشنار (Pride\&O.C.Ferrell,2003:35) الى ان الحصة السوقية تمثل النسبة العئوية للبيع الفعلي

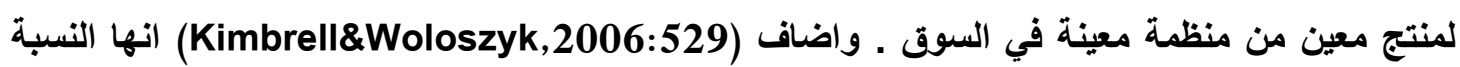

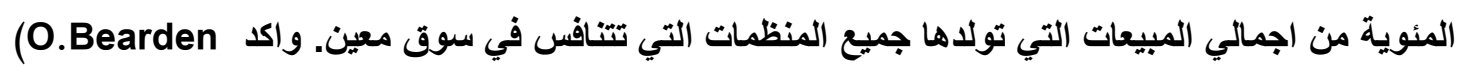

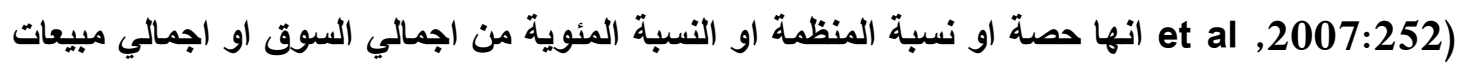

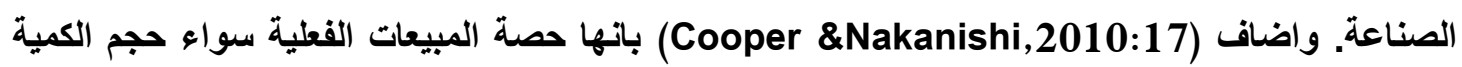

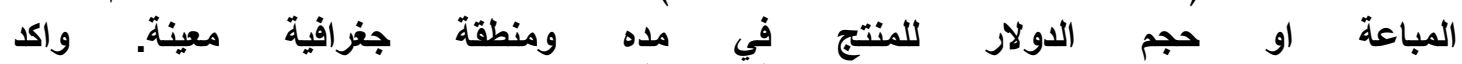

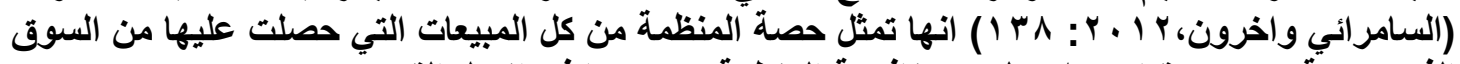

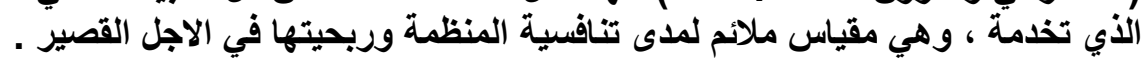

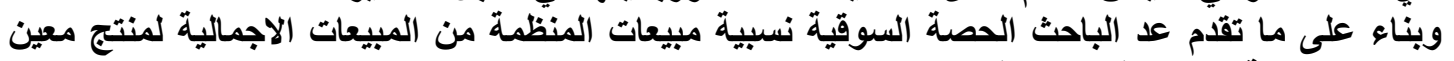

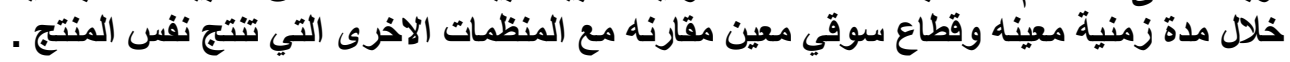

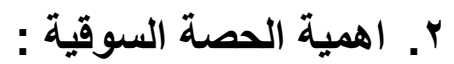

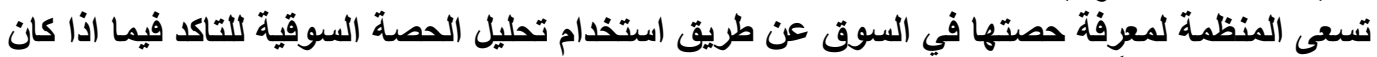

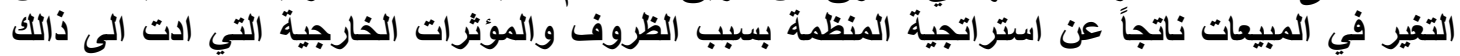

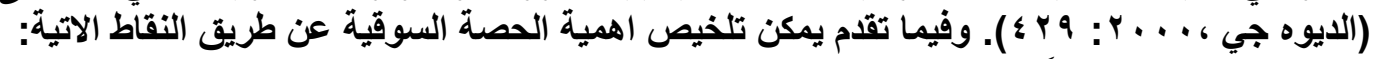

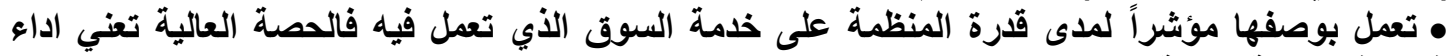

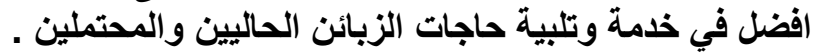

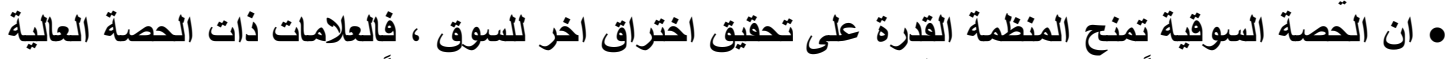

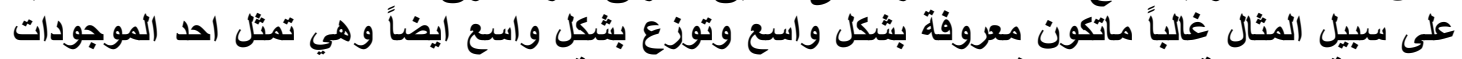

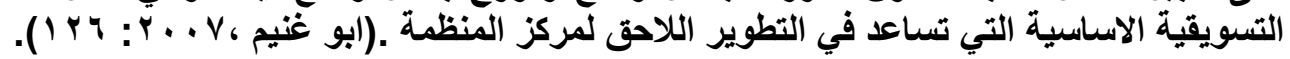

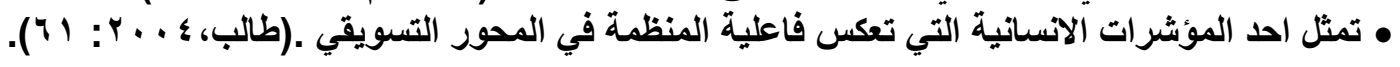

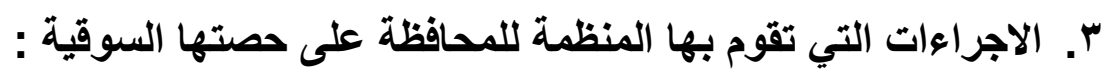




\section{شركات الاتصال اللهاتف المهمول في العراق}

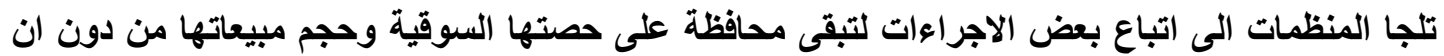

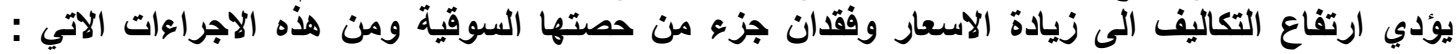

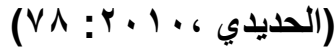

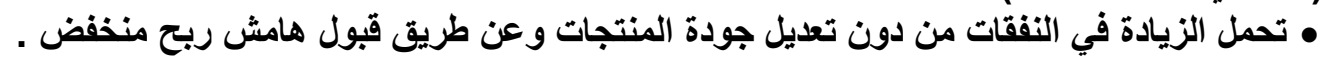

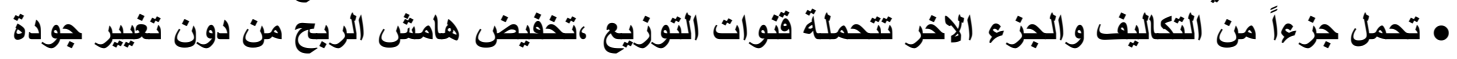
المنتجات . • تعديل الجودة بشكل يخفض النفقات والمحافظة على الاسعار وذلك بتخفيض الحجم واستخدام مركبات ذات جودة اقلى.

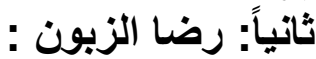

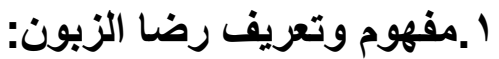
اشـار(Kotler,2000:36) ان رضا الزبون هو تعبير عن مشاعر السعادة والسرور نتيجة لمقارنة

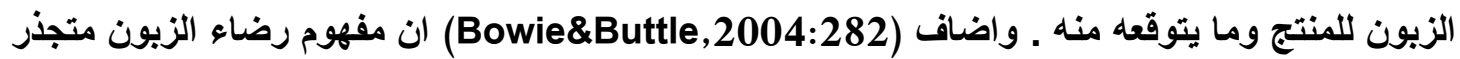
عميقاً في فلسفة التسويق وهو عنصر رئيسي في معظم التعاريف التسويقية ويتفق الاكاديميون والمتمرسين

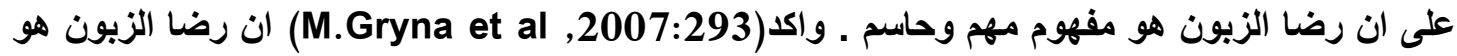

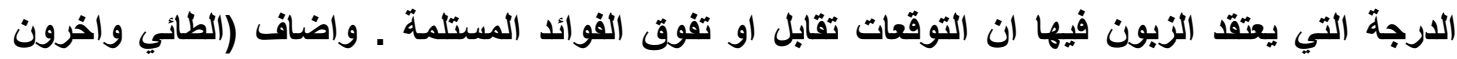

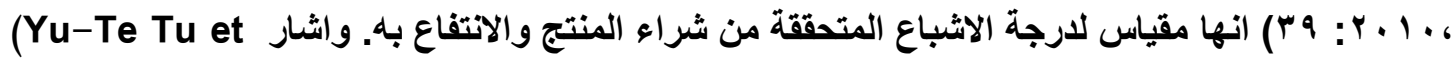
al 2011:200) الى ان رضا الزبون يمكن ان يقسم الى مدخلين رضا صفقه محدده اورضا تراكمي وان

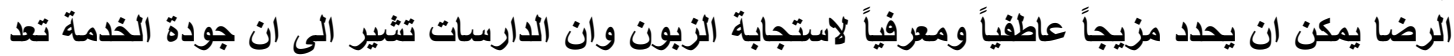

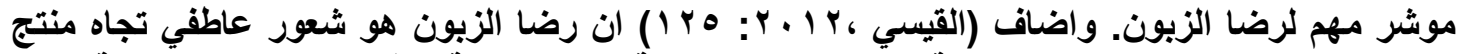

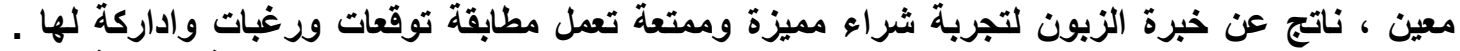

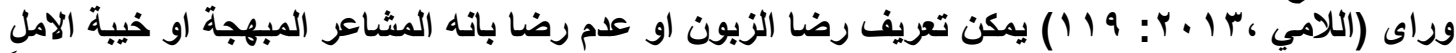

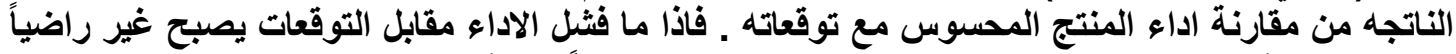

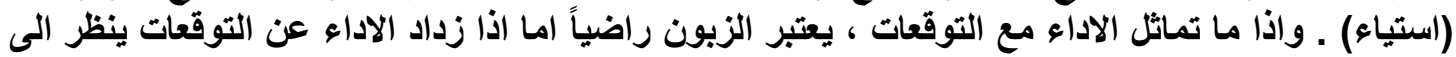


ومن خلال ماتقام نستنتج بان رضا الزبون عبارة عن شعور واحساس نفسي يعبر عن الفرق بين اداء

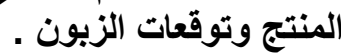

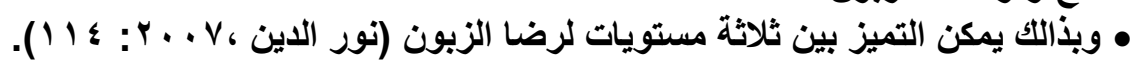

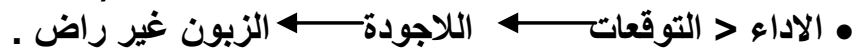

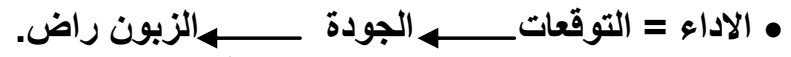

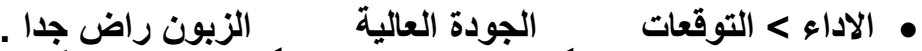

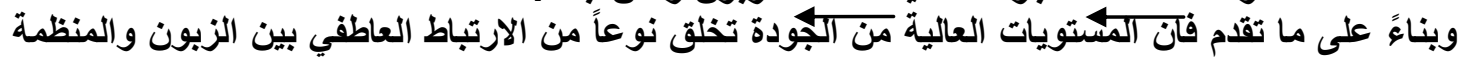

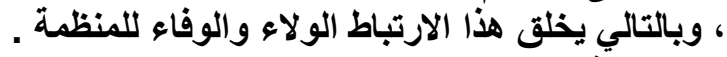

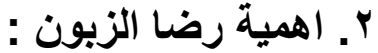

تعد الهمية رضا الزيون من اكثر معايير الفاعلية للحكم على الاداء المنظمي، ولاسيما عندما تكون المنظمة

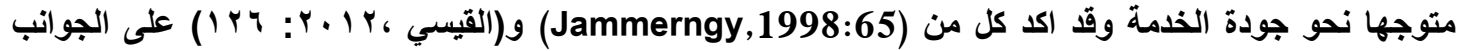

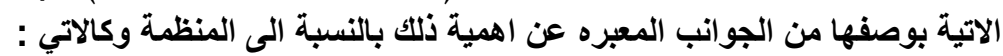

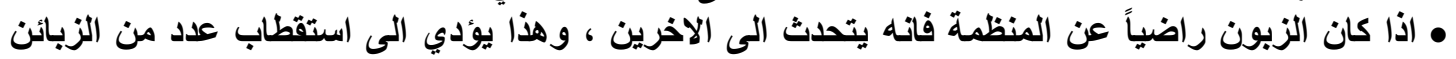
• عندما يكون الزبون راضياً عن الخدمة المقدمة اليه، فان قراره بالرجوع الى الى المنظمة سيكون سريعاً.

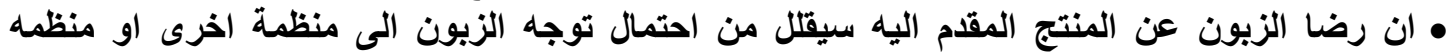
منافسة. • ان المنظمة التي تهنم برضا الزبون ستكون لايها القدرة على حماية نفسها من المنافسين ولاسيما في

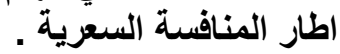

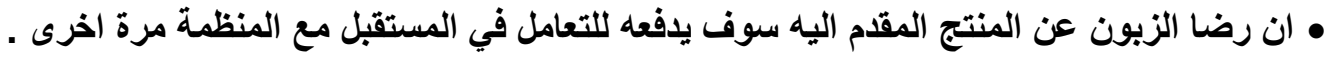

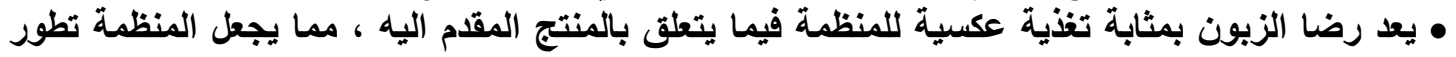

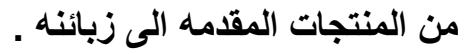

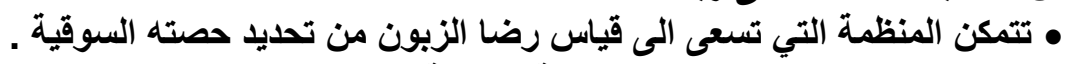

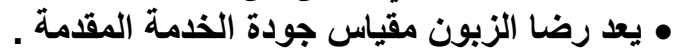

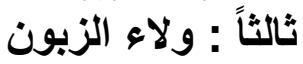

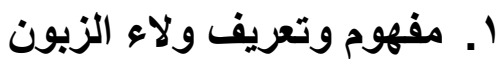

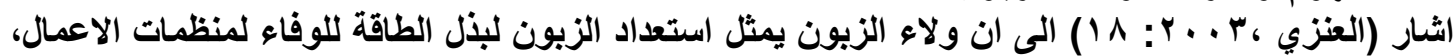

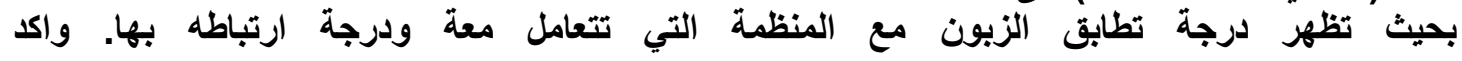
(Rowley,2005:119) (Cooil\&Tul,2007:68) وراى (Sainy,2010:51) ان مواصلة الزبون لرعاية منتجات المنظمة على المدى الطويل ،من خلال

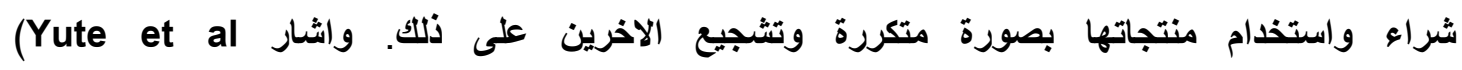
(إه 2011:201,الى انه الولاء للماركة او الخدمة او المحل ـ اي انه موقف ايجابي ينعكس في سلوك الزبون

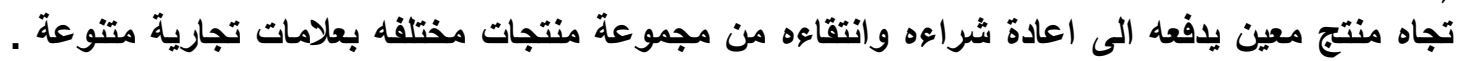

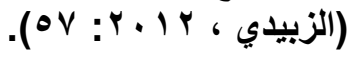




\section{شركات الاتصال اللهاتف المهمول في العراق}

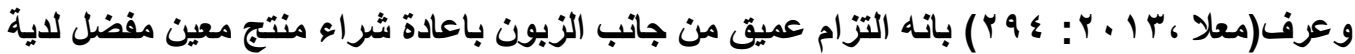

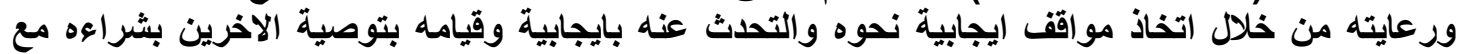

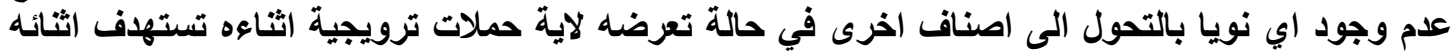

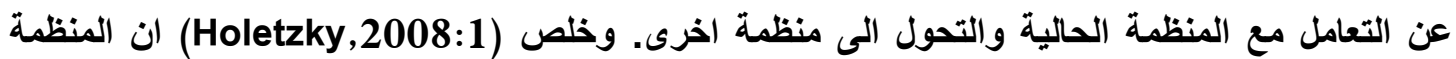

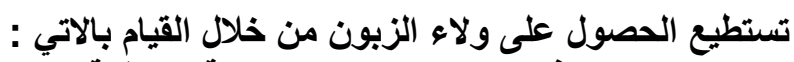

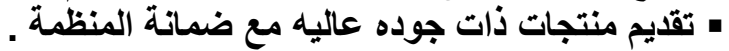

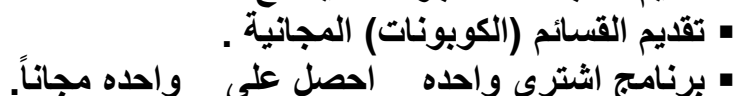

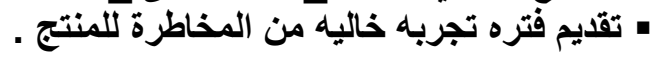

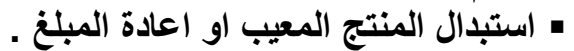
• تقديم هدايا مجانية او خصم .

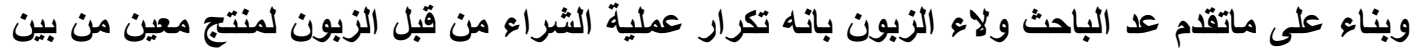

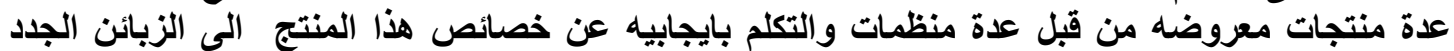

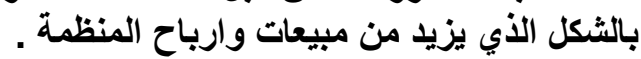

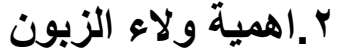

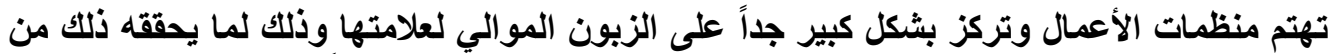

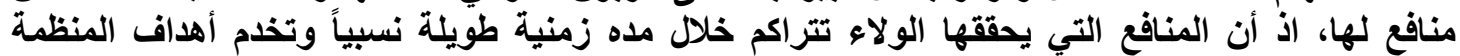

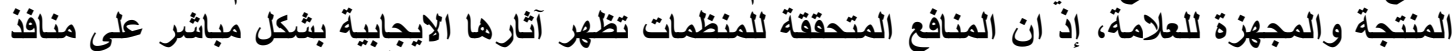
التوزيع بشكل خاص لاحتكاكهم المباشر بالزبون ومعرفة دوافعه ومواقفه، فضلاً عن معرفة سلوكه الثرائة الئي

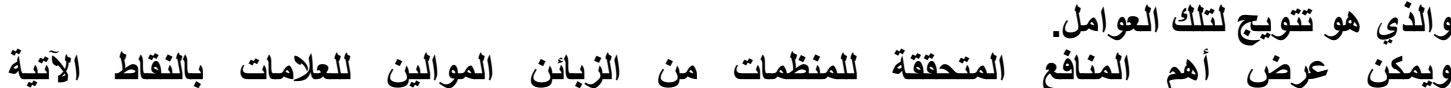

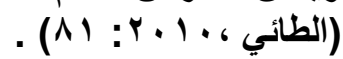

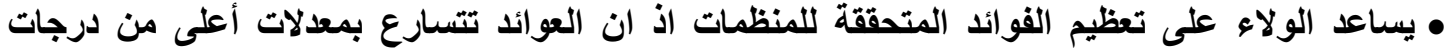

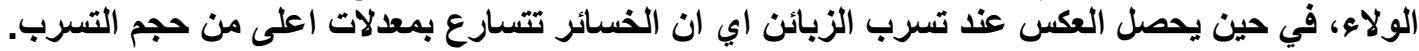

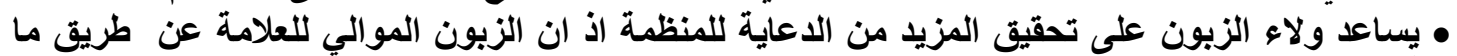

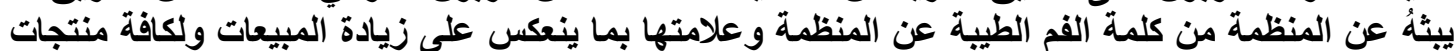
المنظمة . المنه • يُمكن الزبون الوفي لعلامة معينة ان يدفع أسعاراً عالية ويكون أقل حساسية تجاه أسعار المنتجات الموالي • يساعد الولاء على تخفيض التكاليف التسويقية في مجال الترويج والتعريف بالمنظمة وجهود استقطاب

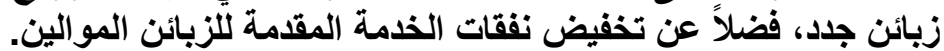
رابعاً: قيمة الزبون فيون

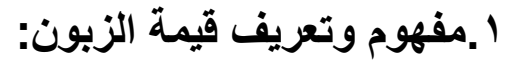

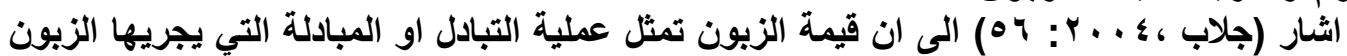

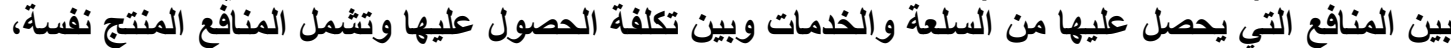

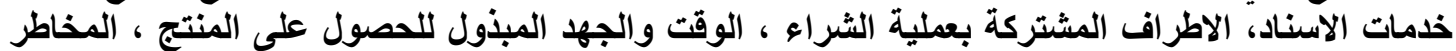

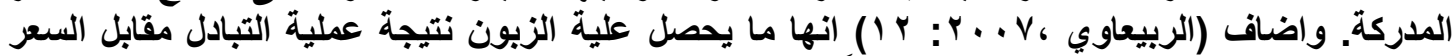

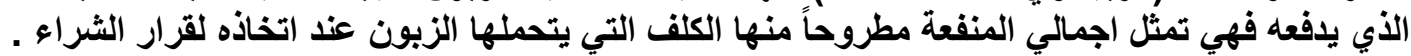




\section{شركات الاتصال للهاتف المحمول في العراق}

وراى (Stone\&Jecobs, 2008:8) ان قيمة الزبون تمثل المجموع الكلي للمعاملات المالية مع الزبائن .واضاف (S.summers,2009:94) انها مدى الاستفادة والمنفعة من المنتج او الخدمة واتلي يتم

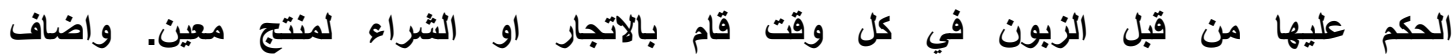
(Hollensen,2011:115) (TeTu et al 2011:199) بانها تقيم الزبون الثامل للمنتج والمستند الى ادراكات ما يستلمه وما يعطيه. وراى (Wang\&Feng,2012:59) ان قيمة الزبون هي مقارنة بين ما يعطي الزبون وياخذه اي النسبة

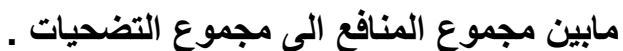

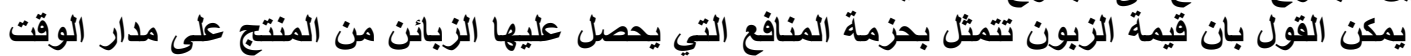

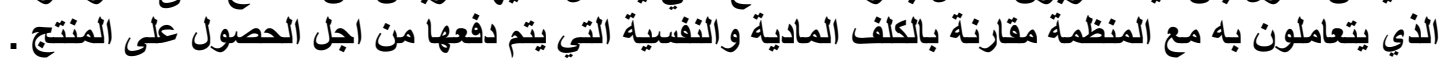

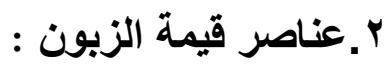

حدد كل من الباحثان (Kotler\&Keller,2009:156) عنصرين اساسين لاجل تكوين قيمة الزيون

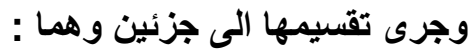

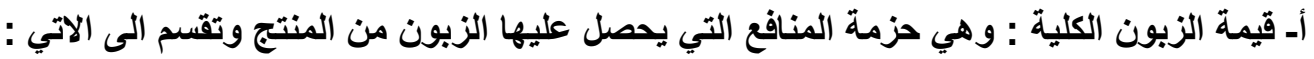

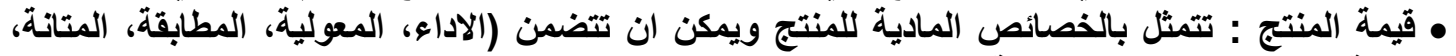

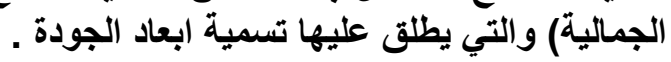

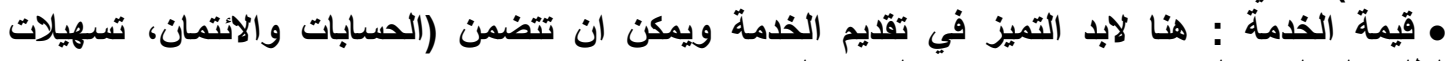

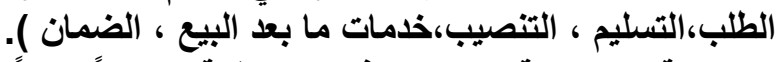

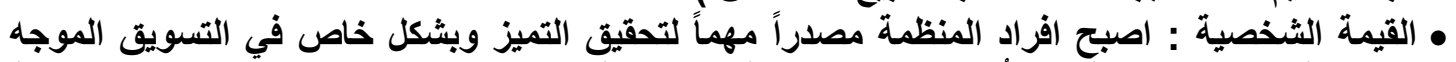

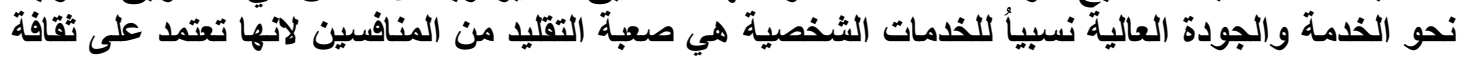

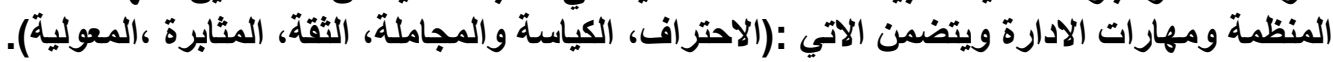

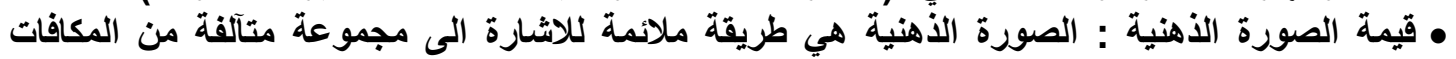

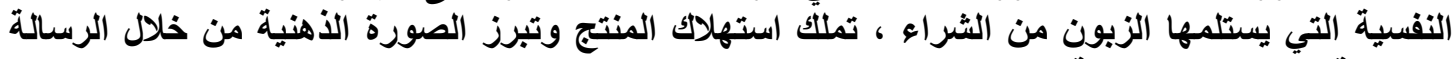
الاعلامية او من خلال التهلية التعبئة .

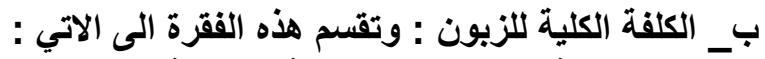
• الكلف النقدية : السعر هو القيمة التبادلية للمنتجات وعلى الآلى اساس تحدد قيمة المنتج التي سيحصل عليها • كلف الوقت : بعض الزبائن يعدون كلفة الوقت اعلى من الكلف النقاية ، وهذا يظهر بوضوح لاى الزبائن

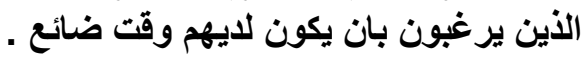

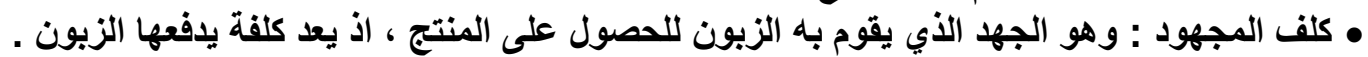

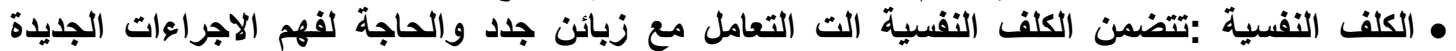

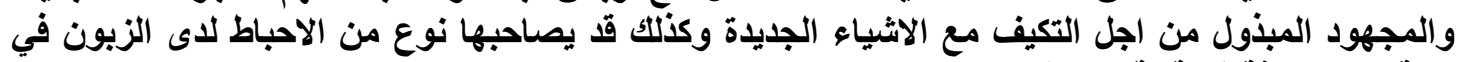

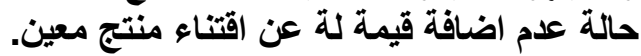

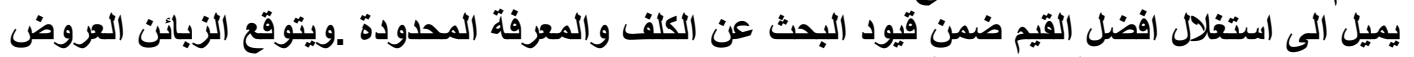

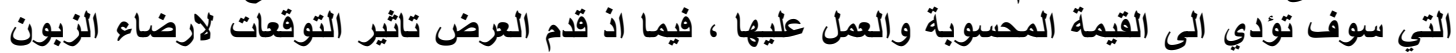

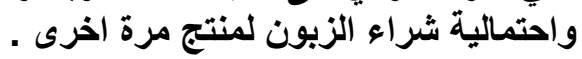




\section{شركات الاتصال اللهاتف المهمول في العراق}

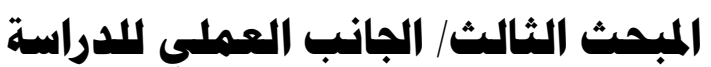

أولاً: اختبار علاقات الارتباط بين متغيرات الاراسة الاساسية المعرفة السوقية ، وتحسين الاداء التسويقي في

الشركات عينة الاراسة علات الآثات

\begin{tabular}{|c|c|c|c|c|c|c|c|}
\hline & كات | & بابعاده الفرعياً & الاداء التسو & 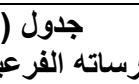 & نية السوقي & الارتباط بين & علاة \\
\hline & زين لل & بعاده الفرعية & | التسويقي & ساته الفرعية & السوقية بم & الارتباط بين م & علاقان \\
\hline عنوية & العلا & & & & & & الاداء \\
\hline النسبية & العدد & التسمويقي الاداء & الزبونة & الزبونy3 & الزيونسى & السوقية الحصة & \\
\hline $100 \%$ & 5 & $.562 * *$ & $.475 * *$ & $.522 * *$ & $.389 * *$ & $.429 * *$ & الزبون1 xعة \\
\hline $100 \%$ & 5 & $.549 * *$ & $.420 * *$ & $.258^{* *}$ & $.518^{* *}$ & $.358 * *$ & المنافسين20 \\
\hline $100 \%$ & 5 & $.554^{* *}$ & $.555^{* *}$ & $.395 * *$ & $.569 * *$ & $.253^{* *}$ & السوق30 البحاث \\
\hline $100 \%$ & 5 & $.740 * *$ & $.656^{* *}$ & $.499 * *$ & $.626 * *$ & $.477 * *$ & \\
\hline & 20 & & & & & العدد & \\
\hline $100 \%$ & & & & & & الاهسبية & \\
\hline كالات & U & ه الفرعية لثة & التسويقي & هـ الفرعية وال & وقية بممار & تباط بين معري & \\
\hline عنوية & العلا| & & & & & & الاداء \\
\hline الاهبية & العدد & التسويقي الاداء & الزبونيمة y4 & الزبونy3 ولاء & الزبونى y2 & السوقية y1 & \\
\hline $100 \%$ & 5 & $.609 * *$ & $.523 * *$ & $.418^{* *}$ & $.577^{* *}$ & $.625 * *$ & الزبون1فة \\
\hline $100 \%$ & 5 & $.744 * *$ & $.731 * *$ & $.638^{* *}$ & $.680 * *$ & $.733 * *$ & المنافسينف2 \\
\hline $100 \%$ & 5 & $.817 * *$ & $.796 * *$ & $.654^{* *}$ & $.754^{* *}$ & $.816 * *$ & السوق33 البحاث \\
\hline $100 \%$ & 5 & $.780 * *$ & $.740 * *$ & $.606 * *$ & $.717^{* *}$ & $.793 * *$ & السوقيةة المعة \\
\hline & 20 & & & & & العدد & \\
\hline $100 \%$ & & & & & & النسبية & المعنوية \\
\hline
\end{tabular}




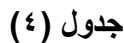

علاقات الارتباط بين معرفة السوقية بممارساته الفرعية والاداء التسويقي بابعاده الفرعية لشركة كورك للاتصالات

\begin{tabular}{|c|c|c|c|c|c|c|c|}
\hline \multicolumn{2}{|c|}{ العلاقات المعنوية } & \multirow[b]{2}{*}{ التسمويقي الاداء } & \multirow[b]{2}{*}{ الزيونيمة y4 } & \multirow[b]{2}{*}{ الزبوناء و3 } & \multirow[b]{2}{*}{ رضيون2 رالزئ } & \multirow[b]{2}{*}{ السوقية الحصة } & \multirow{2}{*}{ / التسويقي } \\
\hline الاهبية & العدد & & & & & & \\
\hline $100 \%$ & 5 & $.706 * *$ & $.397 * *$ & $.520 * *$ & $.750 * *$ & $.473 * *$ & الزبون معرفة \\
\hline $100 \%$ & 5 & $.710 * *$ & $.579 * *$ & $.600^{* *}$ & $.575^{* *}$ & $.303^{*}$ & المنافسين2 \\
\hline $100 \%$ & 5 & $.745^{* *}$ & $.667^{* *}$ & $.524 * *$ & $.625^{* *}$ & $.382 * *$ & السوق33 السحاث \\
\hline $100 \%$ & 5 & $.851 * *$ & $.648 * *$ & $.659 * *$ & $.747 * *$ & $.450 * *$ & السوقرفة المبة \\
\hline \multirow[b]{2}{*}{$100 \%$} & 20 & & & & & 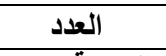 & \multirow{2}{*}{ المعنوية } \\
\hline & & & & & & النسبية & \\
\hline \multicolumn{8}{|c|}{ *الارتباط ذات الدلالة المعنوية عند مستوى (1 ...')(*) } \\
\hline & & & & & مستوى (م) & الدلالة المعنوية & الارتباط ذات \\
\hline
\end{tabular}

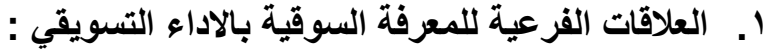

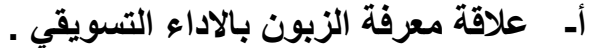

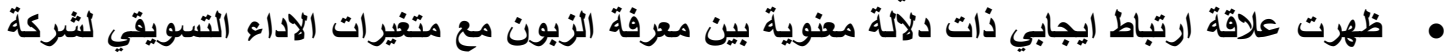

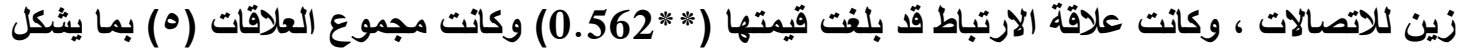

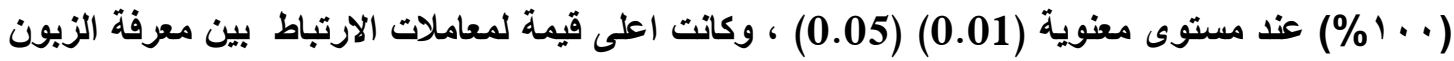

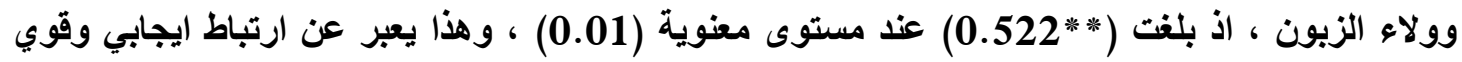

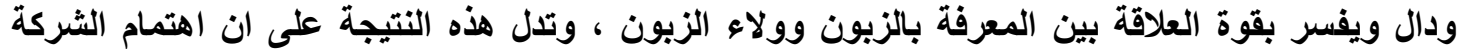

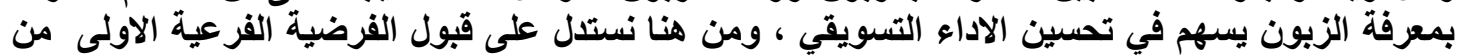
الفرضية الرئيسة الاولى والتي مفادها هناك علاقة ارتباط ذات دلاتلة معنوية لمعرفة الزبون فيون في تحسين الاداء • وظهرت علاقة ارتباط ايجابية ذات دلالة معنوية بين معرفة الزبون وابعاد الاداء التسويقي لشركة

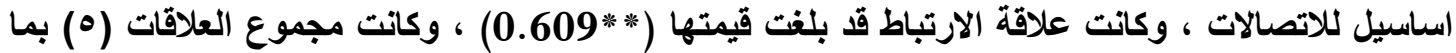

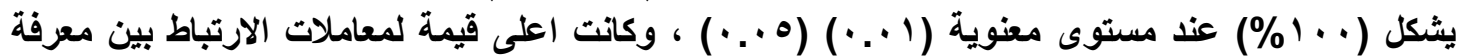

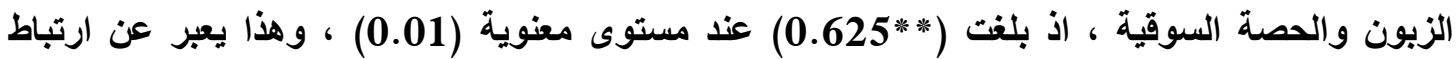

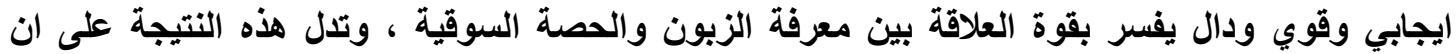

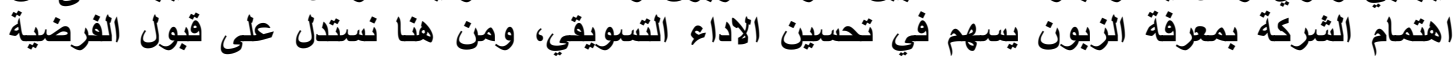

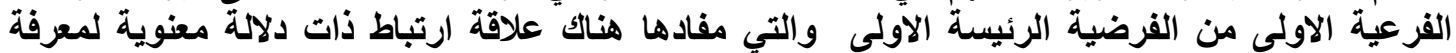
الزبون في تحسين الاداء التسويقي.

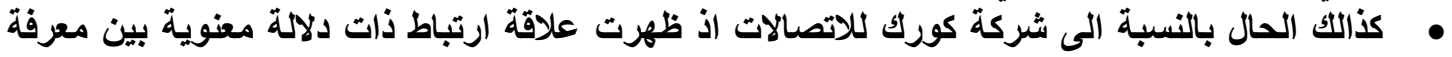

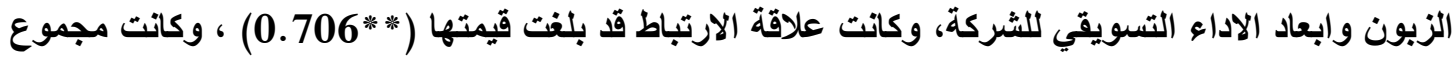

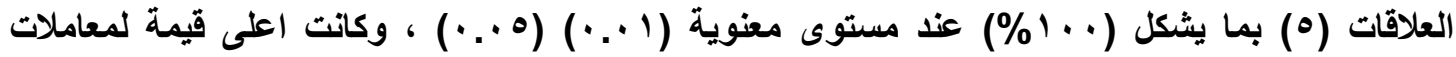




\section{شركات الاتصال للهاتف المحمول في العراق}

الارتباط بين معرفة الزيون ورضا الزيون ، اذ بلغت (*0.750) عند مستوى معنوية (0.01) ، وهذا وفا يعبر

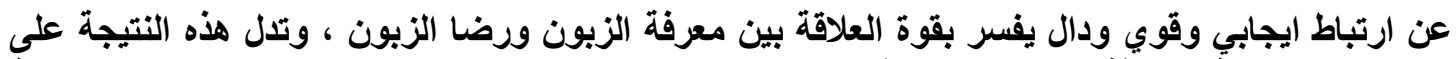

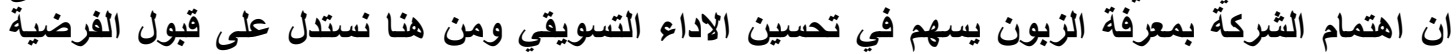

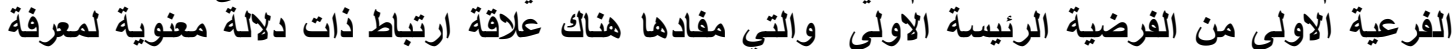

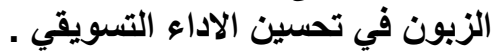

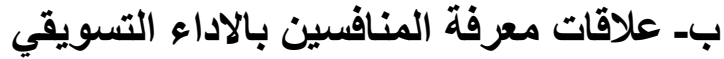

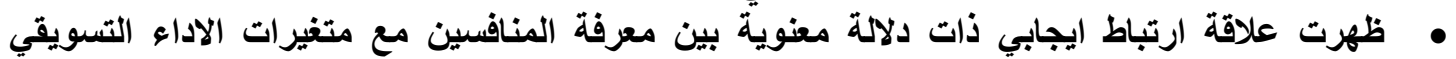

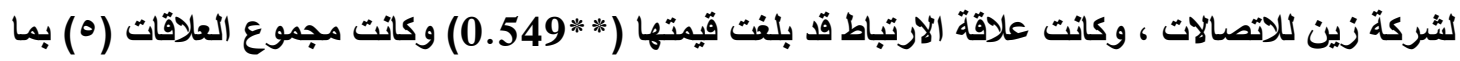
يشكل ( · ( 1\%) عند مستوى معنوية (0.01) (0.05) ، وكاتت اعلى قيمة لمعاملات الارتباط بين معرفة

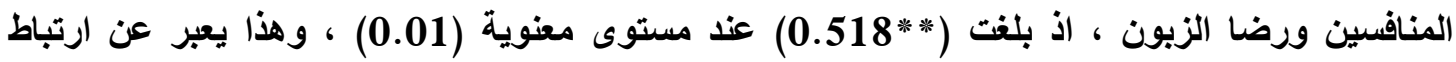

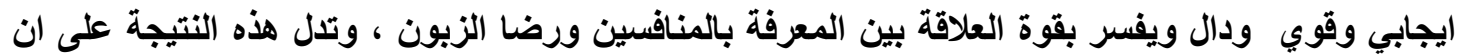

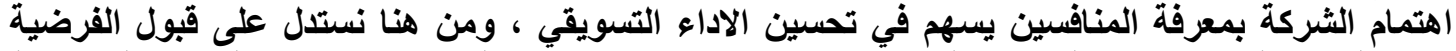

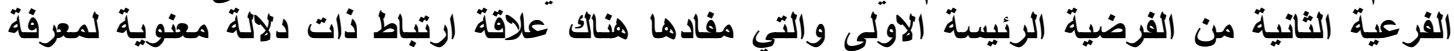

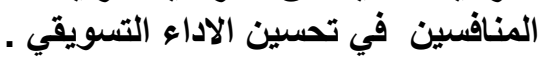
• وظهرت علاقة ارتباط ايجابية ذات دلالة معنوية بين معرفة المنافسين وابعاد الاداء التسويقي لثركة

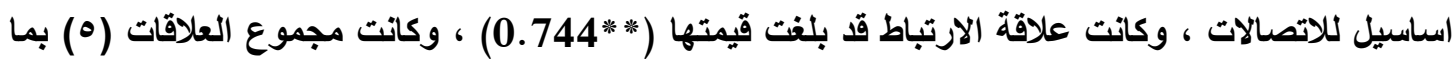

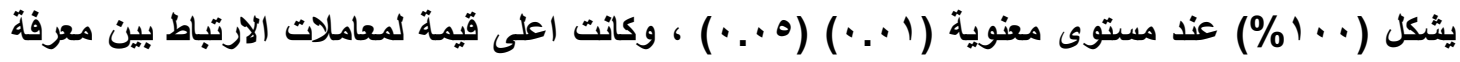

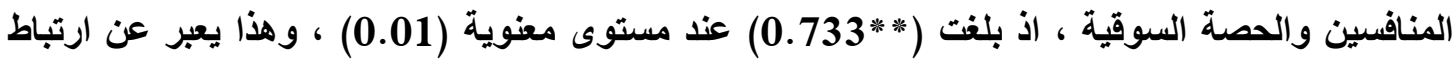

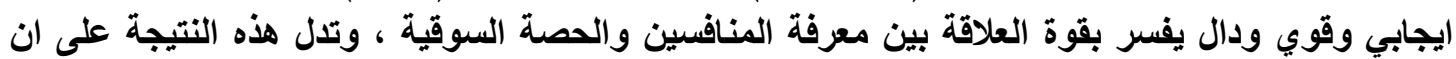

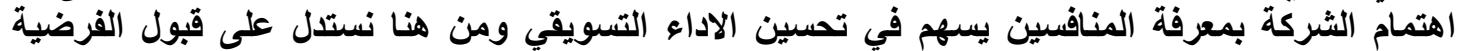

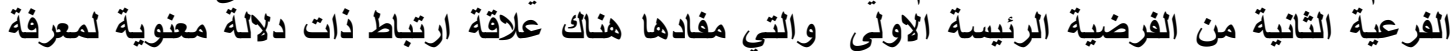

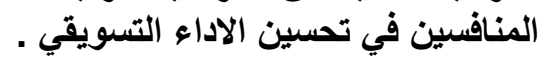

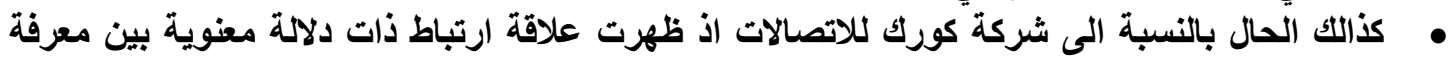

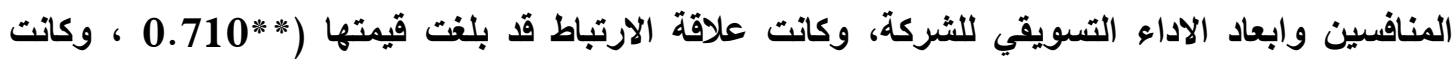

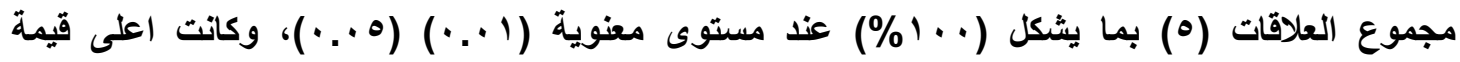

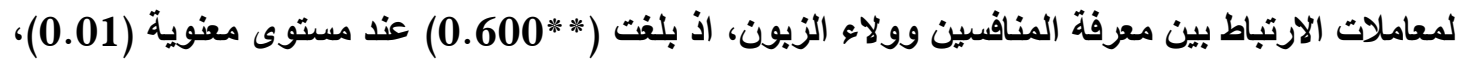

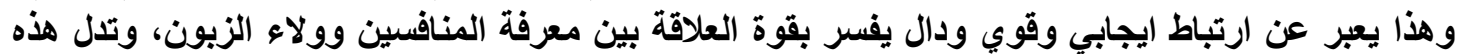

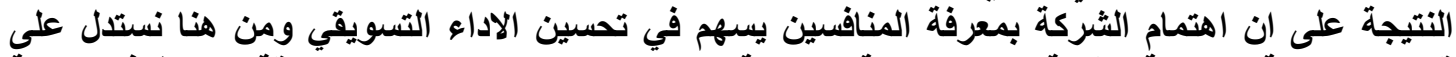

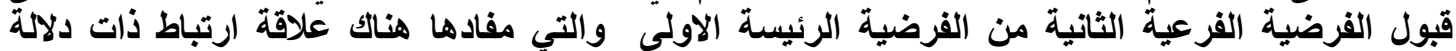

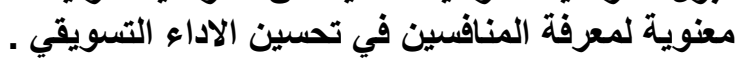


ج- علاقة ابحاث السوق بالاداء التسويقي

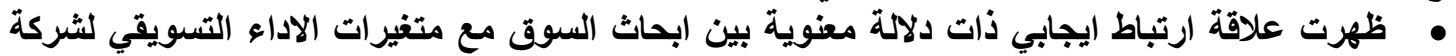

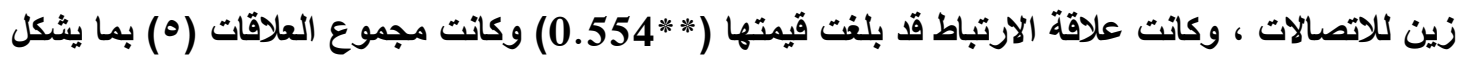

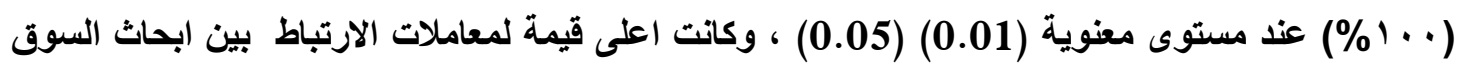

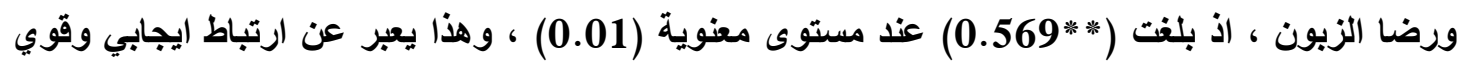

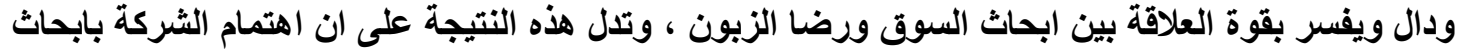

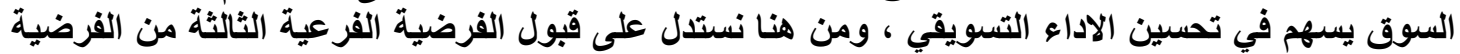
الرئيسة الاولى والتي مفادها هناك علاقة ارتباط ذات دلالة معنوية لابحاث السون التول في تحسين الاداء التسويقي • وظهرت علاقة ارتباط ايجابية ذات دلالة معنوية بين ابحاث السوق وابعاد الاداء التسويقي لشركة

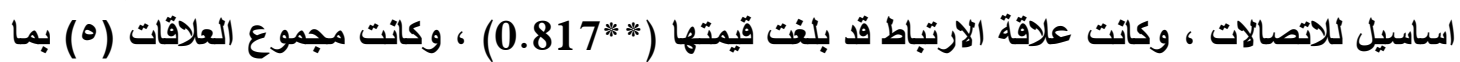

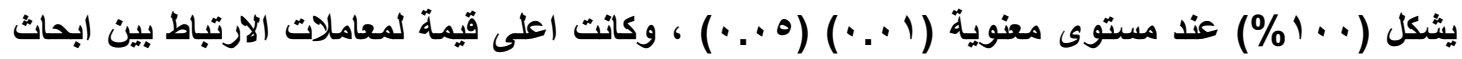

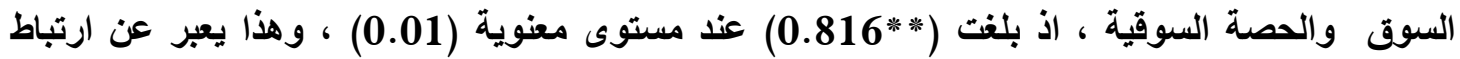

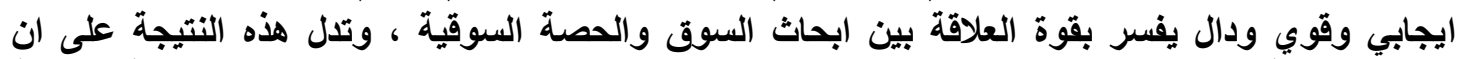

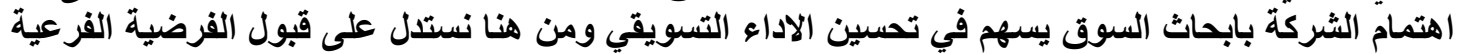

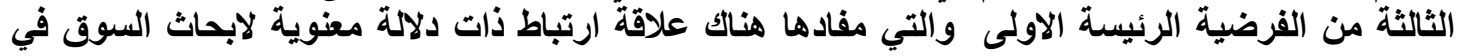
تحسين الاداء التسويقي . • كذالك الحال بالنسبة الى شركة كورك للاتصالات اذ ظهرت علاقة ارتباط ذات دلالة معنوية بين ابحاث

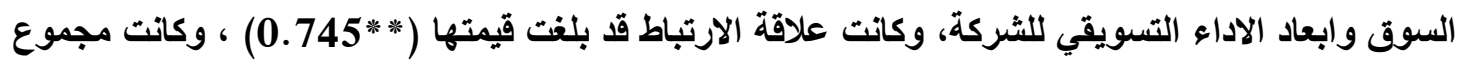

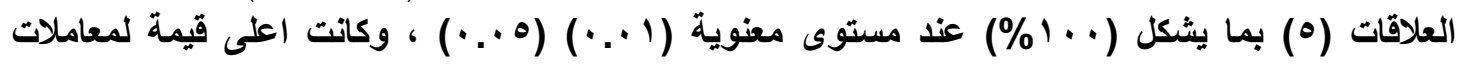

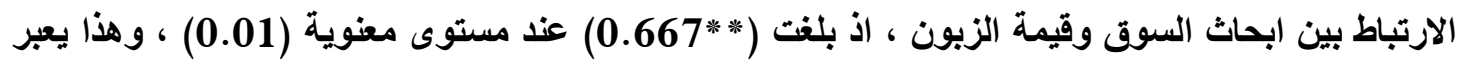

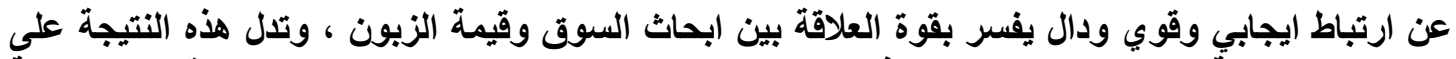

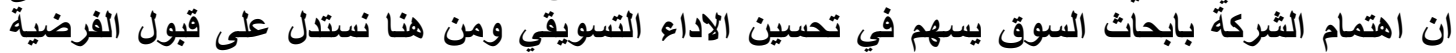

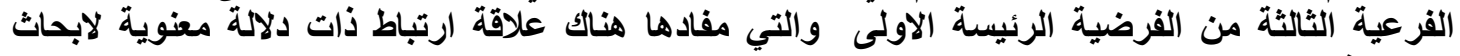

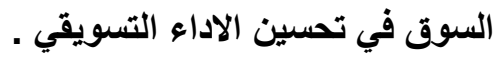

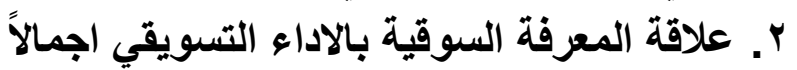
أـ ظهرت علاقة ارتباط ايجابية ذات دلالة معنوية بين متغير المعرفة السوقية ومتفير الاداء التهوفية التسويقي

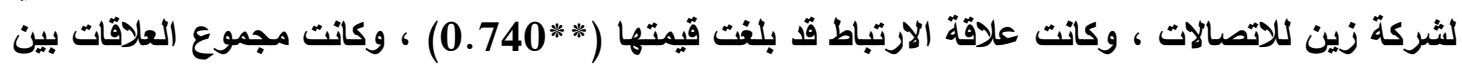

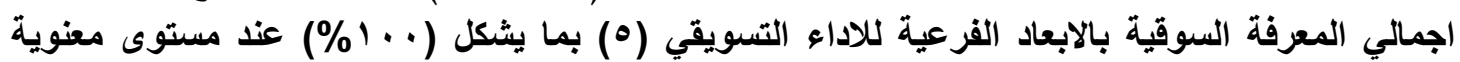

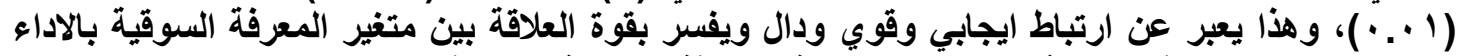

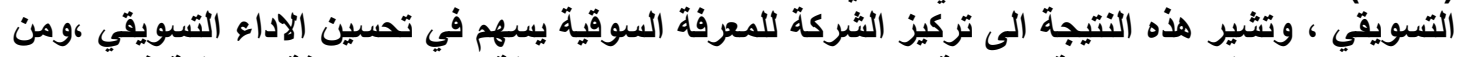

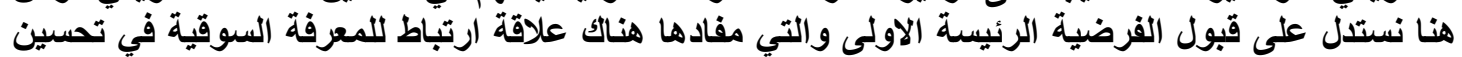
الاداء التسويقي . علئي 


\section{شركات الاتصال للهاتف المحمول في العراق}

ب- ظهرت علاقة ارتباط ايجابية ذات دلالة معنوية بين متغير المعرفة السوقية ومتغير الاداء التسويقي

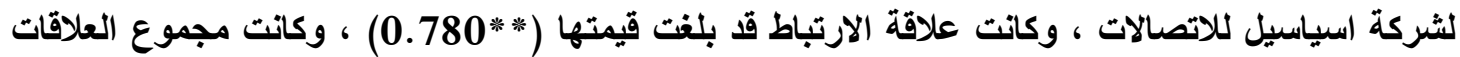

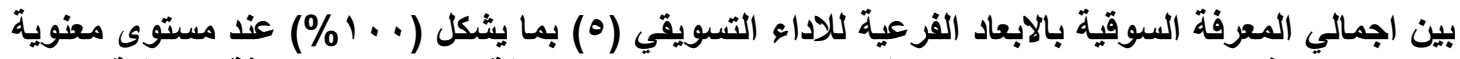

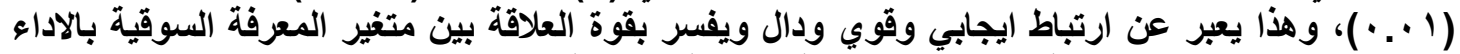

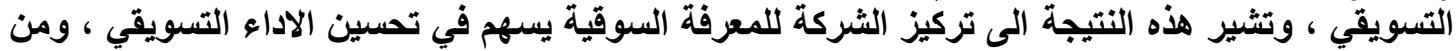

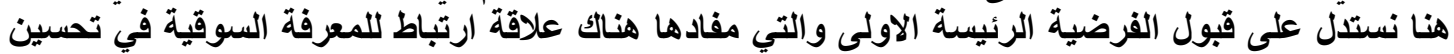
الاداء التسويقي . تـ كذالك بالنسبة الى شركة كورك اذ ظهرت علاقة ارتباط ايجابية ذات دلالة معنوية بين متغير المعرفة

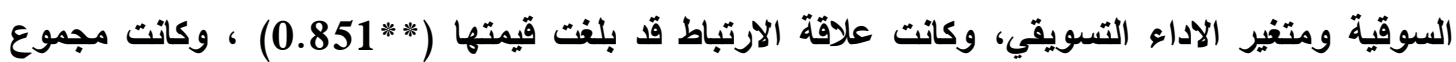

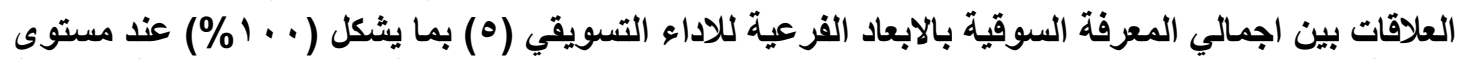

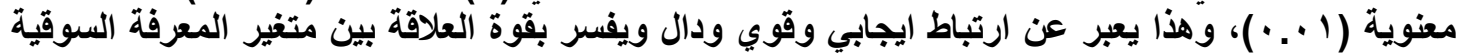

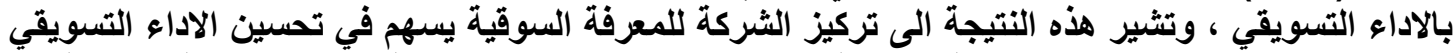

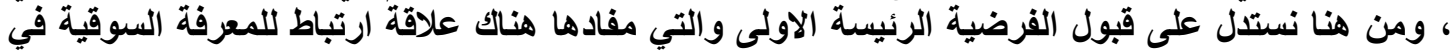

تحسين الاداء التسويقي علئي ثانياً: اختبار وتحليل علاقة التاثير بين متغيرات الدراسة في الثركات عينة الدراسة :

جدول (0)

\begin{tabular}{|c|c|c|c|c|c|c|c|c|c|c|c|c|c|}
\hline \multicolumn{2}{|c|}{ العلاقات المعنوية } & \multirow{2}{*}{\multicolumn{2}{|c|}{ اجمال الاداء التسويقي Y }} & \multirow{2}{*}{\multicolumn{2}{|c|}{ قيمة الزيون Y4 }} & \multirow{2}{*}{\multicolumn{2}{|c|}{ ولاء الزبون Y3 }} & \multirow{2}{*}{\multicolumn{2}{|c|}{ رضى الزبون Y2 }} & \multirow{2}{*}{\multicolumn{2}{|c|}{ الحصة السوقية Y1 }} & & \\
\hline$\%$ & 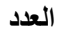 & & & & & & & & & & & & المعر \\
\hline \multirow{2}{*}{$80 \%$} & \multirow{2}{*}{4} & 0.12 & 0.33 & 0.15 & 0.37 & 0.24 & 0.43 & 0.47 & 0.23 & 0.09 & 0.27 & \multirow{2}{*}{\multicolumn{2}{|c|}{$\begin{array}{c}\text { معرفة الزبون X1 } \\
\text { X1 }\end{array}$}} \\
\hline & & دال & 18.54 & دال & 12.57 & دال & 21.54 & غير دال & 3.31 & 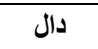 & 7.51 & & \\
\hline \multirow{2}{*}{$80 \%$} & \multirow{2}{*}{4} & 0.19 & 0.25 & 0.15 & 0.3 & 0.02 & 0.1 & 0.2 & 0.4 & 0.09 & 0.22 & \multirow{2}{*}{\multicolumn{2}{|c|}{$\begin{array}{c}\text { معرفة المنافسين X2 } \\
\text { X2 }\end{array}$}} \\
\hline & & دال & 16.66 & دال & 12.44 & غير دال & 1.56 & دال & 17.43 & دال & 6.91 & & \\
\hline \multirow{2}{*}{$80 \%$} & \multirow{2}{*}{4} & 0.22 & 0.34 & 0.26 & 0.5 & 0.08 & 0.26 & 0.13 & 0.41 & 0.04 & 0.19 & \multirow{2}{*}{\multicolumn{2}{|c|}{ ابحاث السوق }} \\
\hline & & دال & 19.2 & دال & 24.09 & دال & 6.48 & دال & 11.02 & غير دال & 3.17 & & \\
\hline \multirow{3}{*}{$100 \%$} & \multirow{2}{*}{5} & 0.36 & 0.53 & 0.32 & 0.66 & 0.15 & 0.43 & 0.27 & 0.62 & 0.13 & 0.4 & \multirow{2}{*}{\multicolumn{2}{|c|}{ السمالي المعرفة }} \\
\hline & & دال & 38.76 & دال & 32.08 & دال & 12.66 & 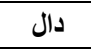 & 18.87 & دال & 10.63 & & \\
\hline & 17 & & & & & & & & & & & العدد & "E \\
\hline $34 \%$ & & & & & & & & & & & & $\%$ & 战 \\
\hline
\end{tabular}


جدول (")

علاقات التاثير بين المعرفة السوقية بمراحله الفرعية والاداء التسويقي بابعاده الفرعية لثركة اسيا سيل للاتصالات

\begin{tabular}{|c|c|c|c|c|c|c|c|c|c|c|c|c|c|}
\hline \multicolumn{2}{|c|}{ العلاقات المعنوية } & \multirow{2}{*}{\multicolumn{2}{|c|}{ اجمال الاداء التسويقي Y }} & \multirow{2}{*}{\multicolumn{2}{|c|}{ قيمة الزبون Y4 }} & \multicolumn{2}{|c|}{ ولاء الزيون Y3 } & \multicolumn{2}{|c|}{ رضى الزيون Y2 } & \multicolumn{2}{|c|}{ العصة السوقية Y1 } & & \\
\hline$\%$ & العدد & & & & & & & & & & & & \\
\hline \multirow{2}{*}{$100 \%$} & \multirow{2}{*}{5} & 0.45 & 0.6 & 0.37 & 0.59 & 0.22 & 0.44 & 0.4 & 0.67 & 0.45 & 0.68 & \multirow{2}{*}{\multicolumn{2}{|c|}{ X1 معرفة الزيون X1 }} \\
\hline & & دال & 48.51 & دال & 35.32 & دال & 16.65 & دال & 39.35 & دال & 46.5 & & \\
\hline \multirow{2}{*}{$100 \%$} & \multirow{2}{*}{5} & 0.58 & 0.7 & 0.56 & 0.75 & 0.42 & 0.63 & 0.39 & 0.69 & 0.47 & 0.73 & \multirow{2}{*}{\multicolumn{2}{|c|}{ X2 معرفة المنافسين }} \\
\hline & & دال & 81.1 & دال & 75.86 & دال & 42.5 & دال & 38.23 & دال & 51.98 & & \\
\hline \multirow{2}{*}{$100 \%$} & \multirow{2}{*}{5} & 0.73 & 0.78 & 0.66 & 0.8 & 0.45 & 0.65 & 0.57 & 0.82 & 0.66 & 0.86 & \multirow{2}{*}{\multicolumn{2}{|c|}{ ابحاث السوق X3 }} \\
\hline & & دال & 163.7 & | دال & 112.52 & دال & 47.65 & ل دال & 77.27 & 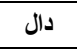 & 113.48 & & \\
\hline \multirow{3}{*}{$100 \%$} & \multirow{2}{*}{5} & 0.69 & 0.82 & 0.62 & 0.85 & 0.42 & 0.68 & 0.54 & 0.87 & 0.62 & 0.91 & \multirow{2}{*}{\multicolumn{2}{|c|}{ السولي المعرفة Xمئة }} \\
\hline & & دال & 133.53 & دال & 97.57 & دال & 42.72 & دال & 68.28 & دال & 95.19 & & \\
\hline & 20 & & & & & & & & & & & \multirow{2}{*}{\multicolumn{2}{|c|}{ 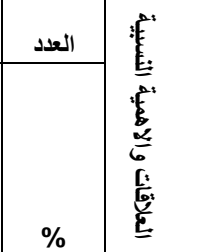 }} \\
\hline $40 \%$ & & & & & & & & & & & & & \\
\hline
\end{tabular}

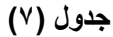

علاقات التاثير بين المعرفة السوقية بمراحله الفرعية والاداء التسويقي بابعاده الفرعية لثركة كورك للاتصالات

\begin{tabular}{|c|c|c|c|c|c|c|c|c|c|c|c|c|c|}
\hline ت ت المعنوية & & \multirow{2}{*}{\multicolumn{2}{|c|}{ التسويقي الاداء }} & \multirow{2}{*}{\multicolumn{2}{|c|}{ قيمة الزبون Y4 }} & \multirow{2}{*}{\multicolumn{2}{|c|}{ ولاء الزبون Y3 }} & \multirow{2}{*}{\multicolumn{2}{|c|}{ رضى الزبون Y2 }} & \multirow{2}{*}{\multicolumn{2}{|c|}{ الحصة السوقية Y1 }} & \multirow{2}{*}{\multicolumn{2}{|c|}{ المعرفة المسوقية الاداء التسوتقي }} \\
\hline$\%$ & 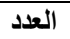 & & & & & & & & & & & & \\
\hline \multirow{2}{*}{$100 \%$} & \multirow{2}{*}{5} & 0.56 & 0.53 & 0.2 & 0.47 & 0.26 & 0.47 & 0.59 & 0.72 & 0.28 & 0.48 & \multirow{2}{*}{\multicolumn{2}{|c|}{ معرفة الزيون X1 }} \\
\hline & & 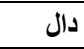 & 61.53 & دال & 12.4 & دال & 16.85 & دال & 71.09 & دال & 19.31 & & \\
\hline \multirow{2}{*}{$60 \%$} & \multirow{2}{*}{3} & 0.33 & 0.26 & 0.48 & 0.46 & 0.06 & 0.15 & 0.38 & 0.37 & 0.01 & 0.07 & \multirow{2}{*}{\multicolumn{2}{|c|}{ X2 معرفة المنافسين }} \\
\hline & & دال & 24.43 & دال & 45.75 & غير دال & 3.58 & دال & 29.76 & غير دال & 0.79 & & \\
\hline \multirow{2}{*}{$60 \%$} & \multirow{2}{*}{3} & 0.34 & 0.24 & 0.52 & 0.43 & 0.04 & 0.1 & 0.38 & 0.33 & 0.02 & 0.08 & \multirow{2}{*}{\multicolumn{2}{|c|}{ ابحاث السوق X3 }} \\
\hline & & دال & 24.81 & دال & 52.66 & غير دال & 2.07 & دال & 29.88 & غير دال & 1.41 & & \\
\hline \multirow{3}{*}{$100 \%$} & \multirow{2}{*}{5} & 0.49 & 0.4 & 0.54 & 0.61 & 0.11 & 0.24 & 0.55 & 0.55 & 0.74 & 0.19 & \multirow{2}{*}{\multicolumn{2}{|c|}{ اجمالي المعرفة السوقية X }} \\
\hline & & دال & 47.39 & دال & 57.81 & دال & 6.13 & دال & 59.12 & دال & 3.82 & & \\
\hline & 16 & & & & & & & & & & & العدد & \multirow{2}{*}{ 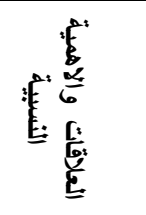 } \\
\hline $32 \%$ & & & & & & & & & & & & $\%$ & \\
\hline
\end{tabular}

\begin{tabular}{|c|c|}
\hline $\mathrm{B}$ & $\mathrm{R}$ \\
\hline $\mathrm{F}$ & $\mathrm{SIG}$ \\
\hline
\end{tabular}


l. . يتضح من الجدول (0) ان قيمة المحسوبة بين معرفة الزيون بوصفة احد مراحل المعرفة السوقية والاداء التسويقي لثركة زين للاتصالات قد بلغت (18.54) وكانت هذه القيمة اكبر من قيمتها الجدولية

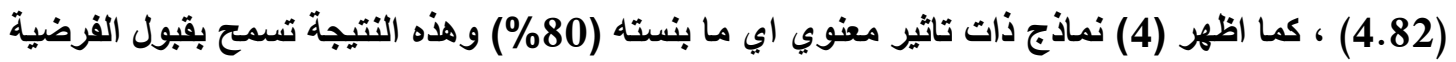

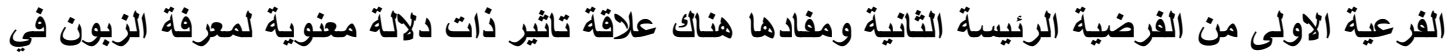

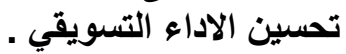
r. فيما يتضح من الجدول (T) ان قيمة F المحسوبة بين معرفة الزيون بوصفة احد مراحل المعرفة السوقية والاداء التسويقي لثركة اسياسيل للاتصالات قد بلغت (48.51) وكانت هذه القيمة اكبر من قيمتها

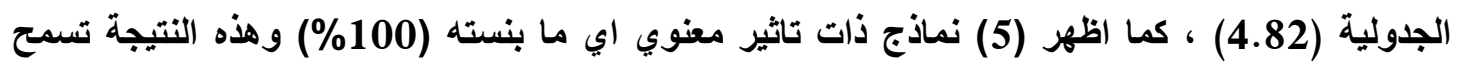

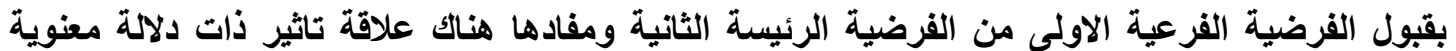

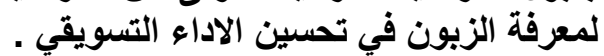
r. اما الجدول (V) يبين ان قيمة F المحسوبة بين معرفة الزبون بوصفة احد مراحل المعرفة السوقية والاداء التسويقي لثركة كورك للاتصالات قد بلغت (61.53) وكاتت هذه القيمة اكبر من قيمتها الجدولية

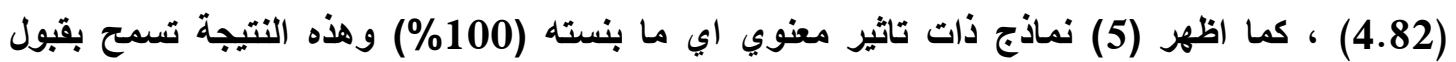

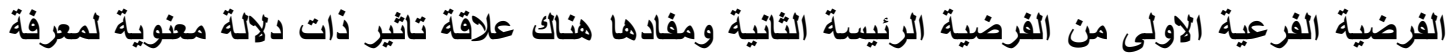

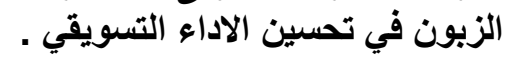
ع. يتضح من الجدول (0) ان قيمة F المحسوبة بين معرفة المنافسين بوصفة احل مراحل المعرفة السوقية

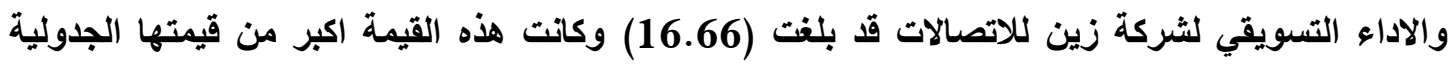

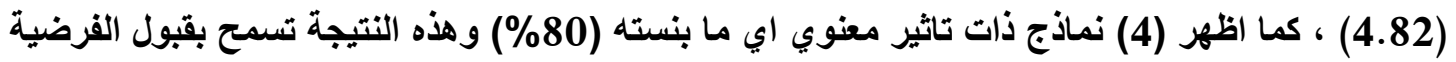

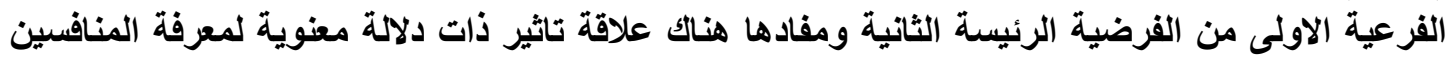
في تحسين الاداء التسويقي. ○. فيما يتضح من الجدول (T) ان قيمة F المحسوبة بين معرفة المنافسين بوصفة احد مراحل المعرفة السوقية والاداء التسويقي لثركة اسياسيل للاتصالات قد بلغت (81.10) وكاتت هذه القيمة اكبر من قيمتها

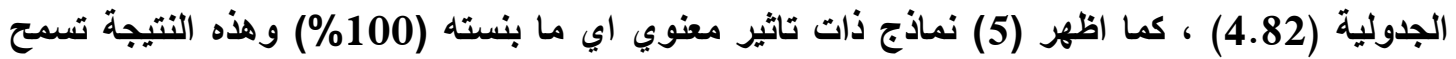

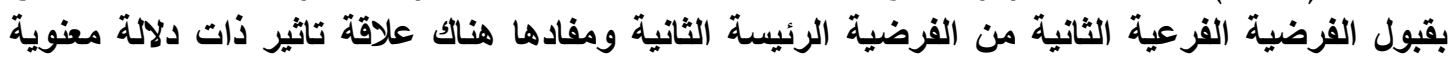

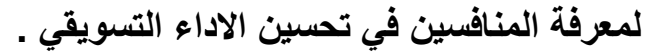

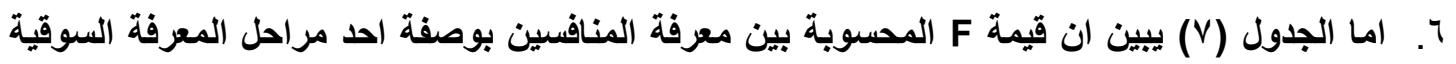
والاداء التسويقي لثركة كورك للاتصالات قد بلفت (24.43) وكاتت هذه القيمة اكبر من قيمتها الجدولية

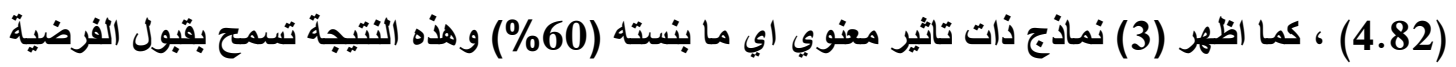

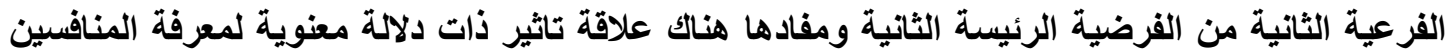
في تحسين الاداء التسويقي. V. يتضح من الجدول (0) ان قيمة F المحسوبة بين ابحاث العوق بوصفة احد مراحل المعرفة السوقية

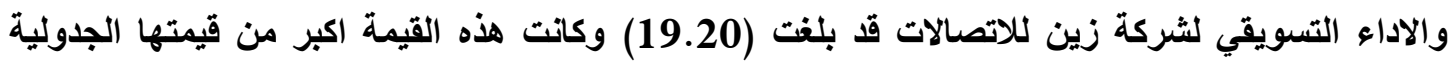

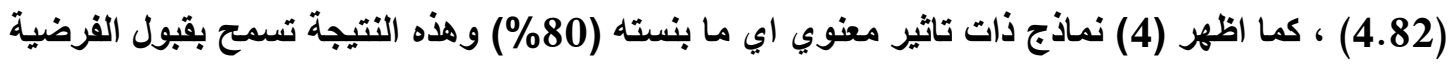

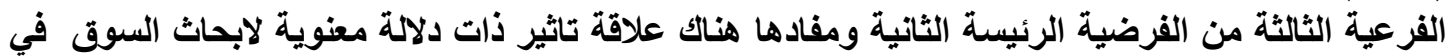


A. فيما يتضح من الجدول (T) ان قيمة F المحسوبة بين ابحاث السوق بوصفة احد مراحل المعرفة

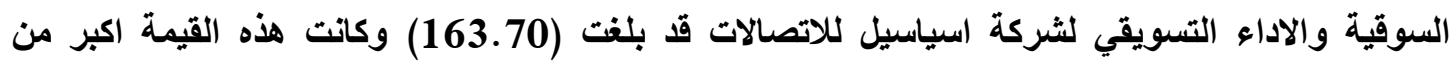

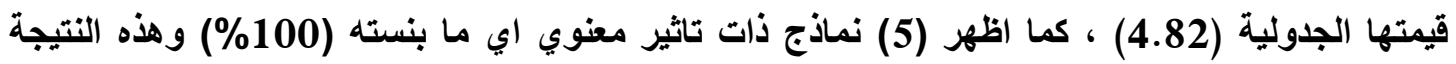

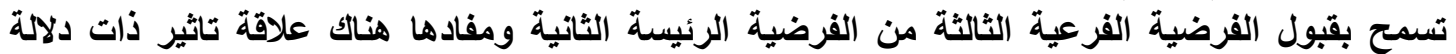

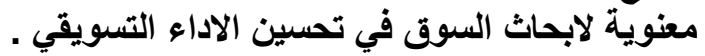

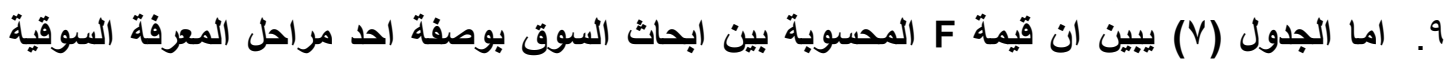
والاداء التسويقي لثركة كورك للاتصالات قد بلفت (24.81) وكاتت هذه القيمة اكبر من قيمتها الجدولية

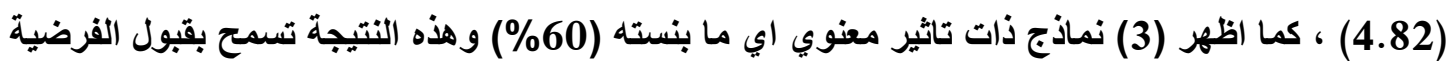

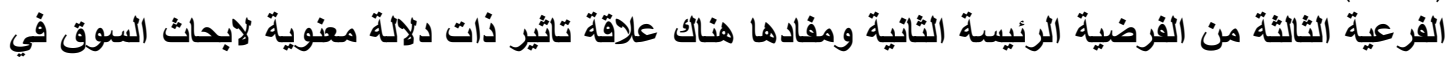
تصسين الاداء التسويقي. • ل ـ يتضح من الجدول (0) ان قيمة F المحسوية بين اجمالي المعرفة السوقية وتحسين الاداء التسويقي لثركة زين للاتصالات قد بلغت (38.76) وكانت هذه القيمة اكبر من قيمتها الجدولية (4.82) ، كما اظهر

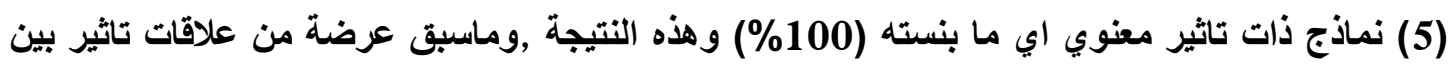

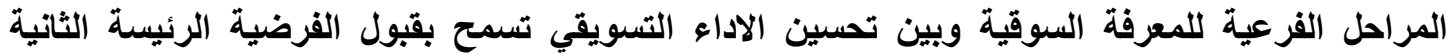

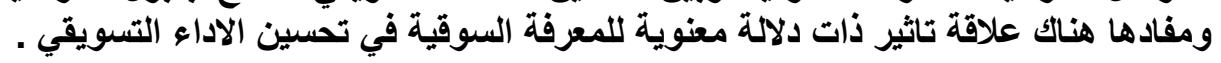

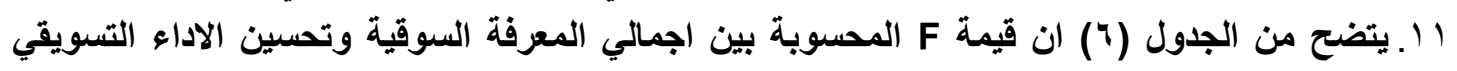

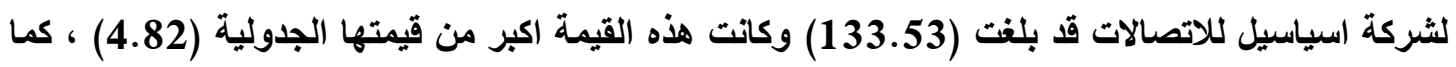

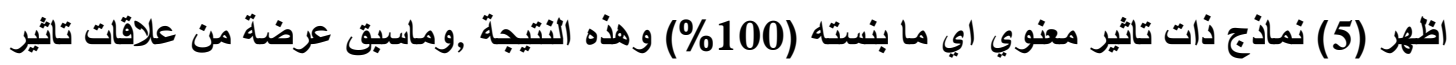

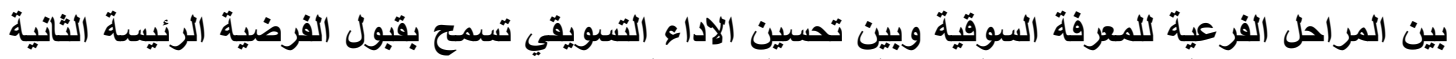

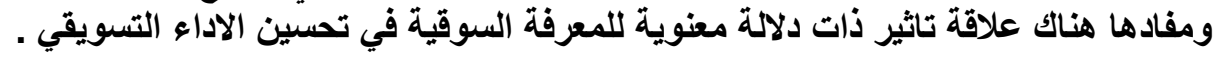

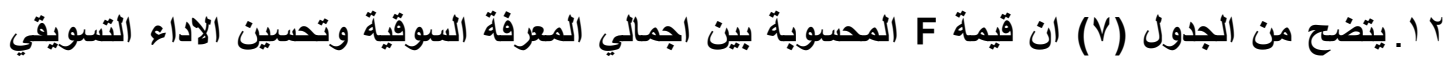

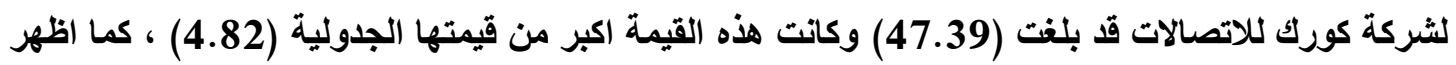

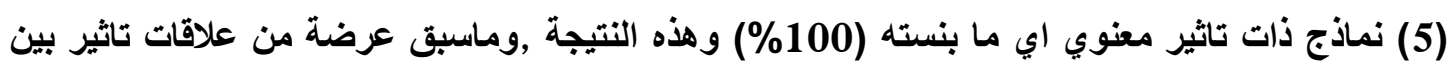

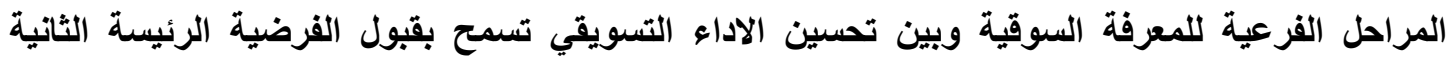
ومفادها هناك علاقة تاثير ذات دلالة معنوية للمعرفة السوقية في تحسين الاداء التسويقي . 
تمخضت هذه الدراسة في جانبها النظري والعملي عن عدد من الاستنتاجات التي يمكن توضيحها فيما

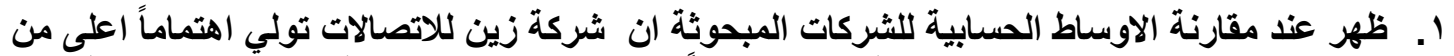

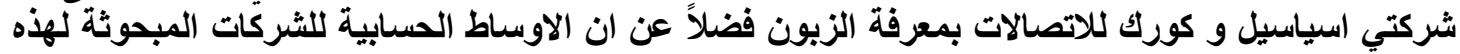

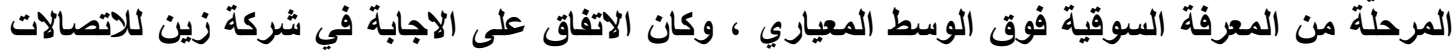

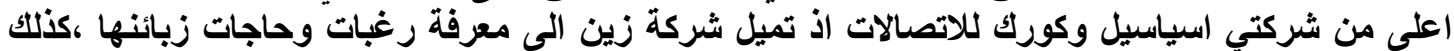

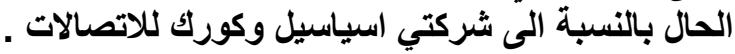

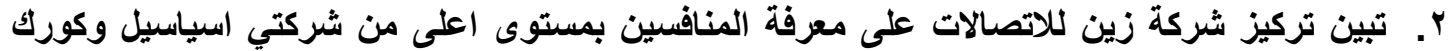

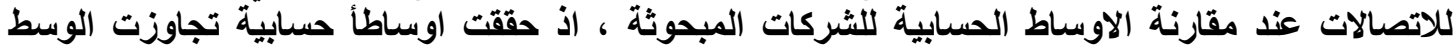

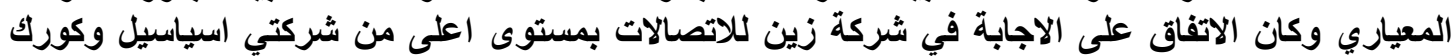

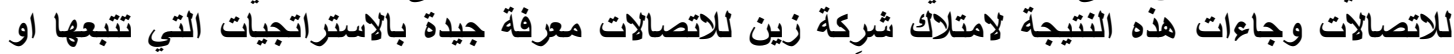

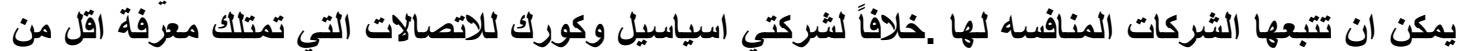

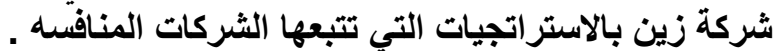

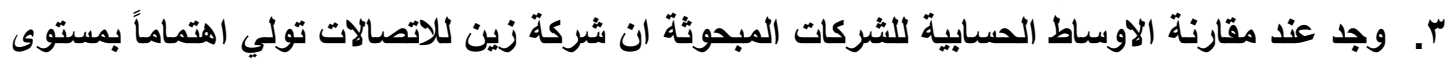

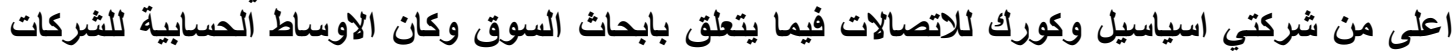

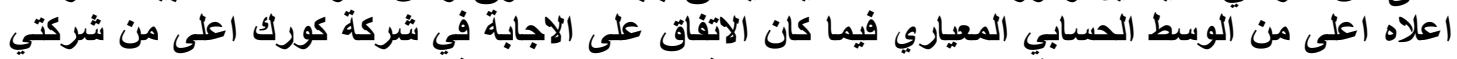

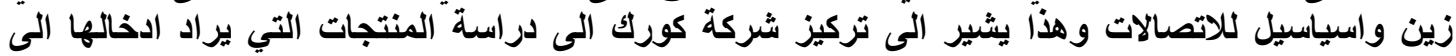

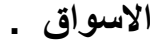
ك. تركز شركة زين للاتصالات على تعزيز الحصة السوقية بمستوى اعلى من شركتي اسياسيل وكورك للاتصالات.

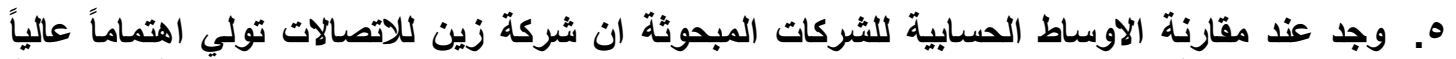

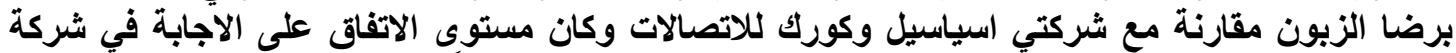

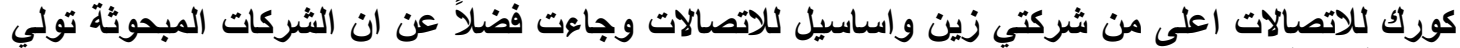

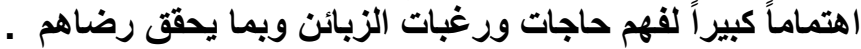

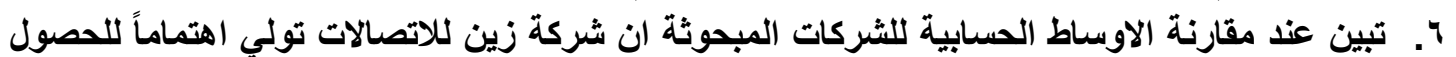

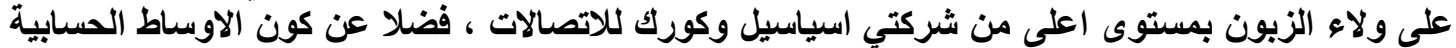

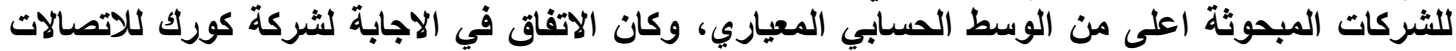

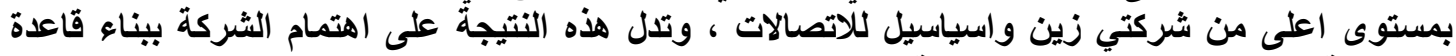

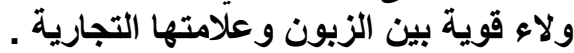

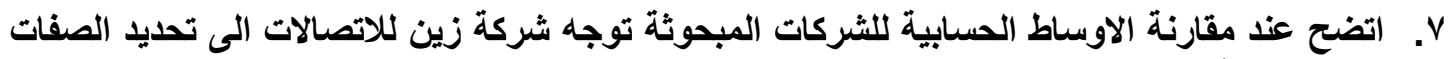

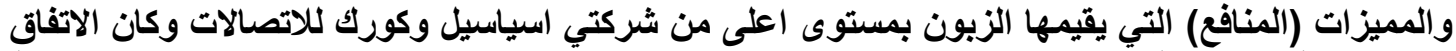

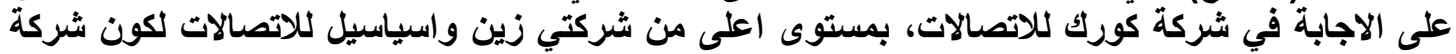

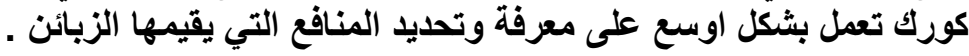

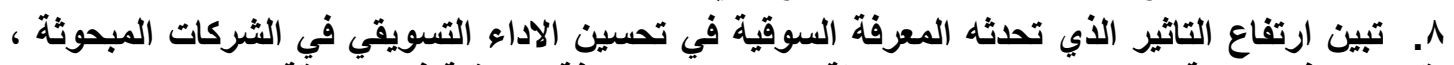

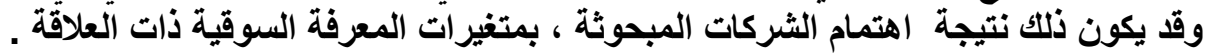




\section{شركات الاتصال اللهاتف المهمول في العراق}

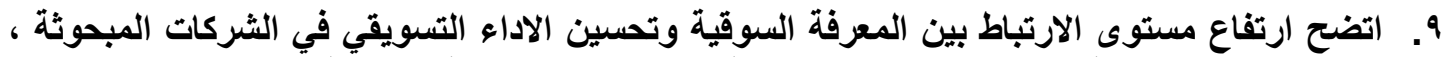

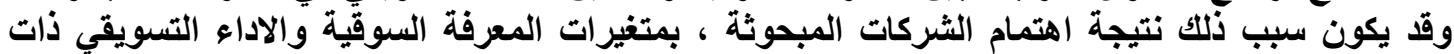
العلاقة .

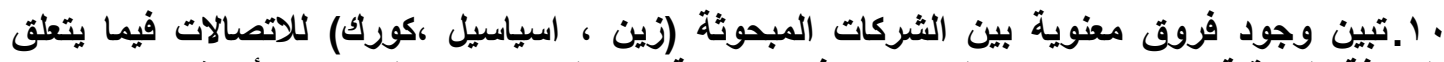

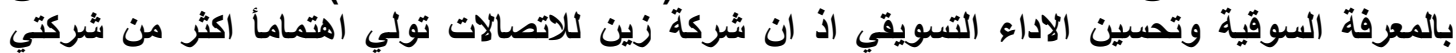

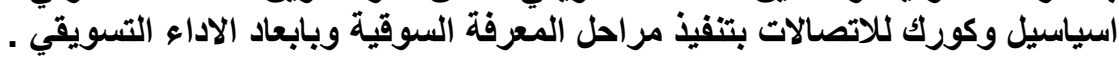

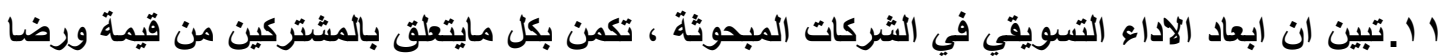
وولاء وبناء علاقات معهم ،فضلا عن التنافس للمحافظة على الحصة الحمات السوقية.

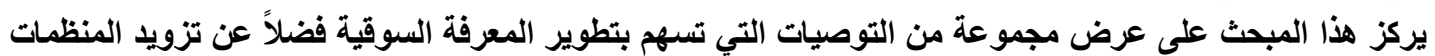

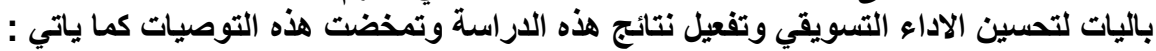

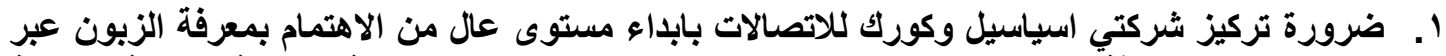

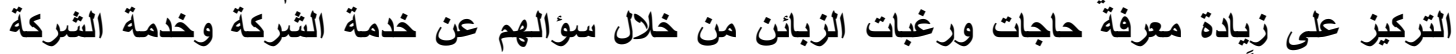

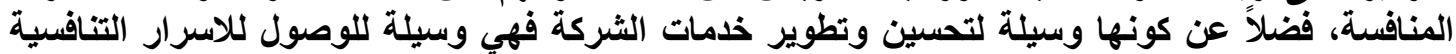

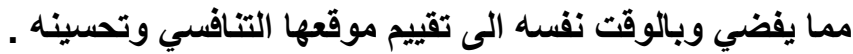

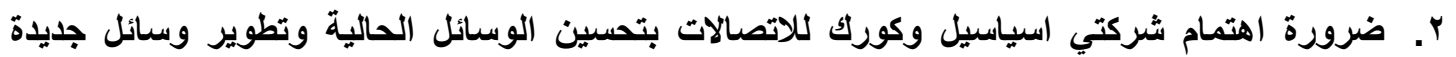

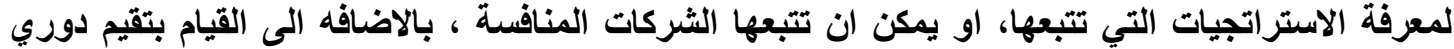

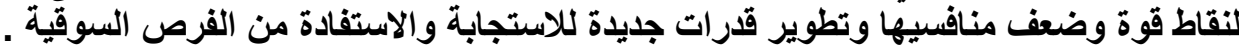

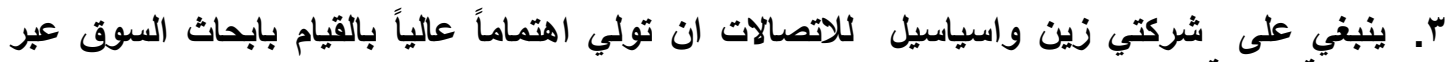

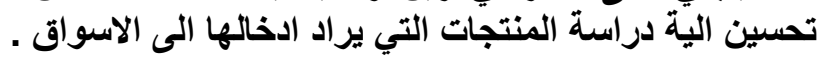

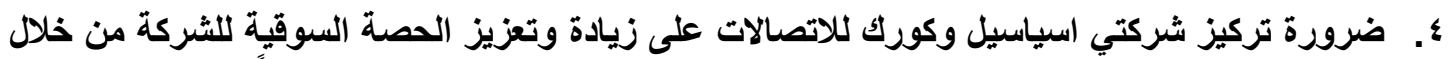

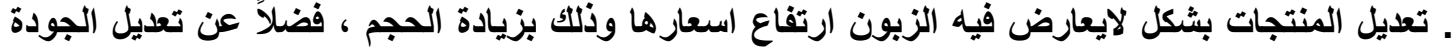

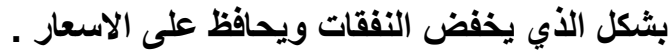
•. ينبفي على شركتي زين واسياسيل للاتصالات ان تولي اهتماماً عالياً في فهم حاجات ورغبات الزبائن

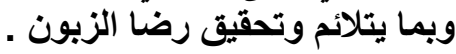
آ. ضرورة انه تولي شركتي زين واسياسيل للاتصالات الى بناء قاعدة ولاء قوية بين الزبون وعلامتها التجارية. V. . ضرورة قيام شركتي زين واسياسيل بالتركيز على تزويد الزبائن بقيمة اعلى من المستوى الحالي لانها

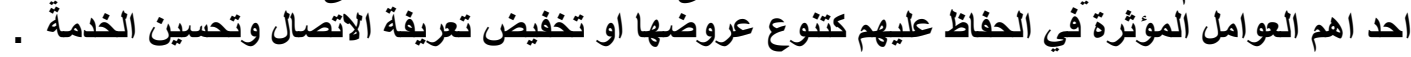

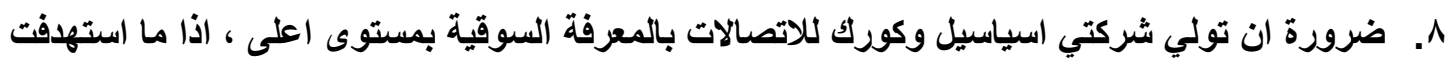

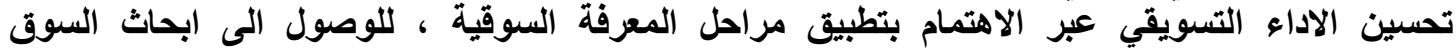
والمتطلبات التي تصب في تحسين الاداء الاء التسويقي .

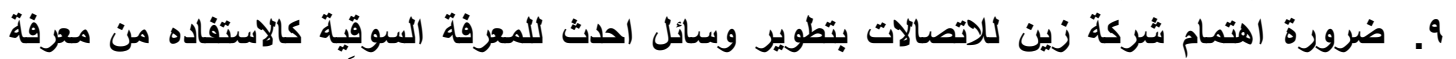

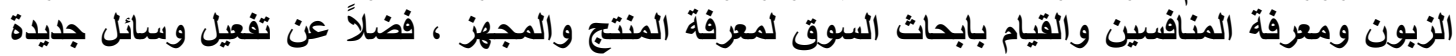

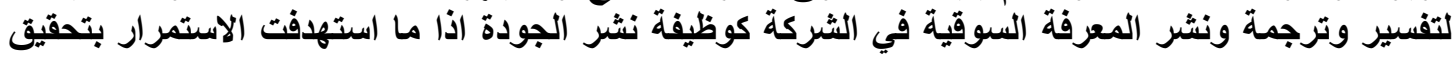




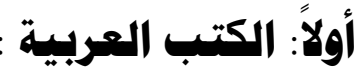

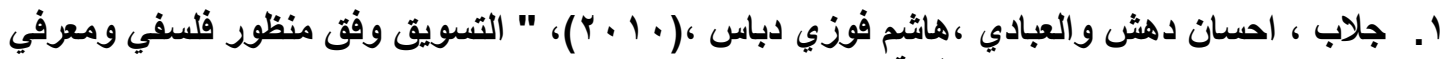

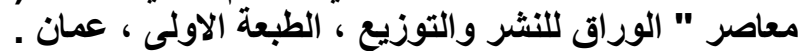

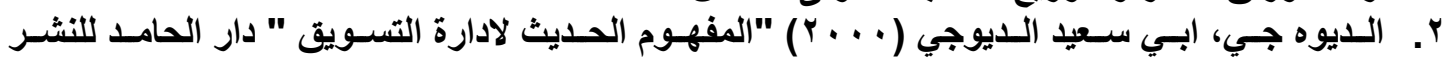

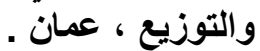

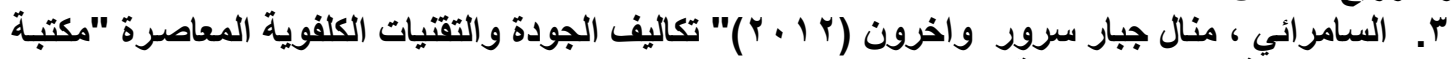

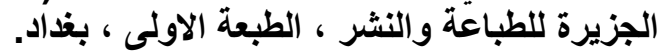

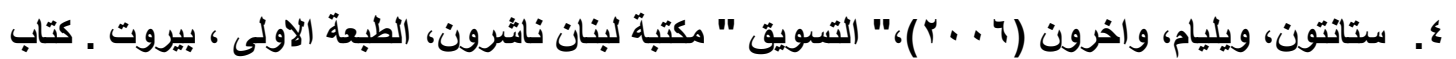

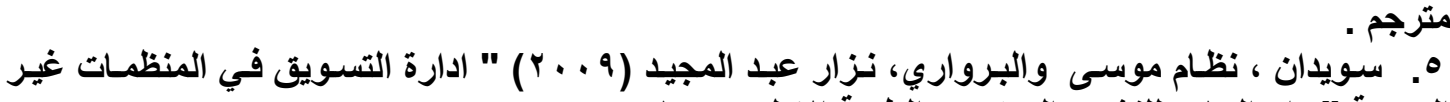

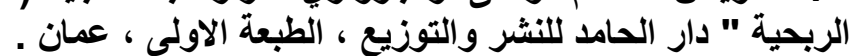

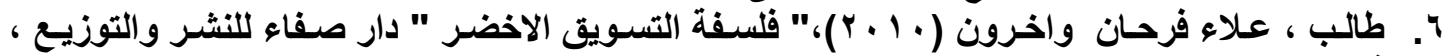

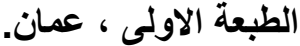

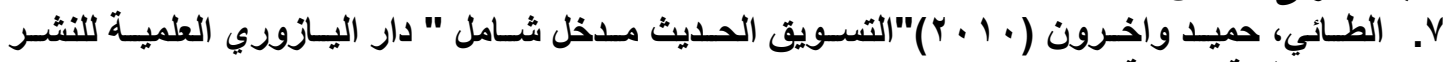

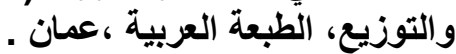

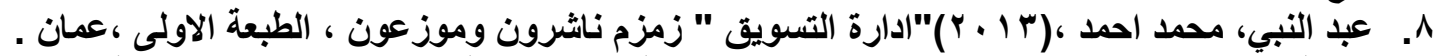

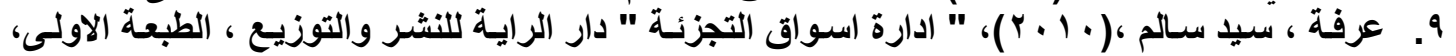

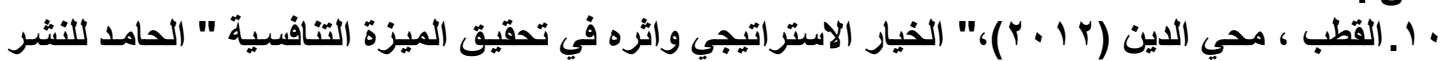
و التوزيع ،الطبعة الاولى ، عمان.

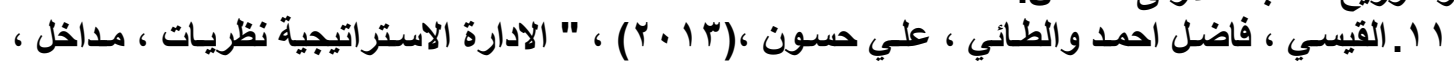

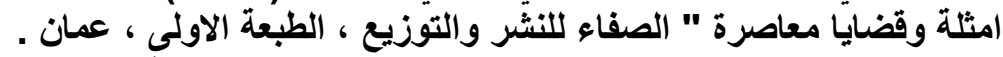

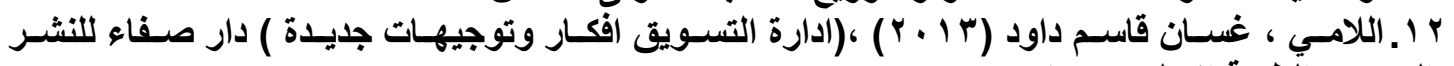

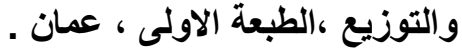

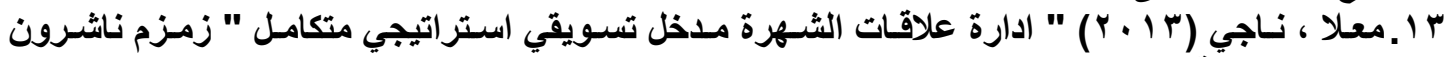

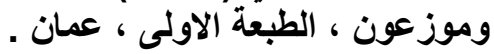




\section{ثانياً: الرسائل والاطاريح :}

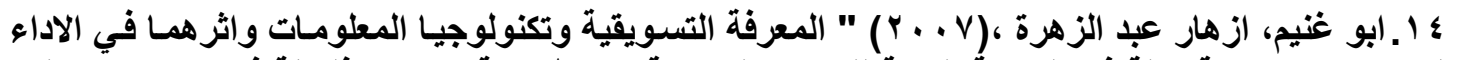

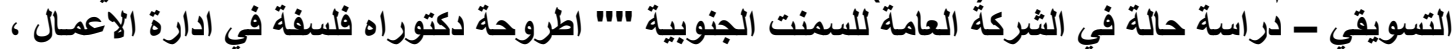

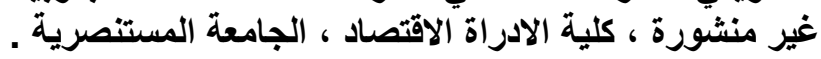

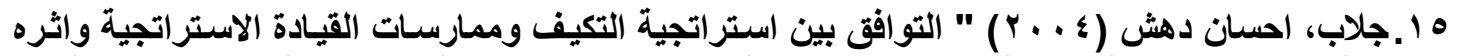

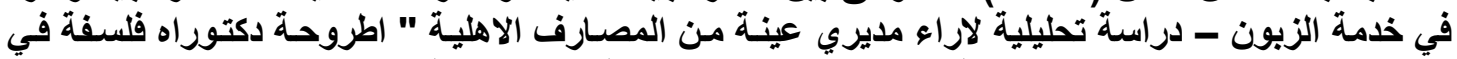

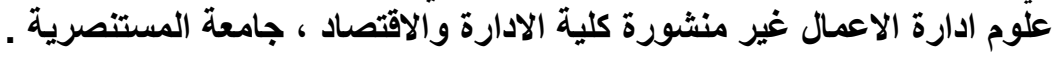

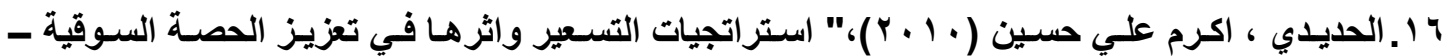

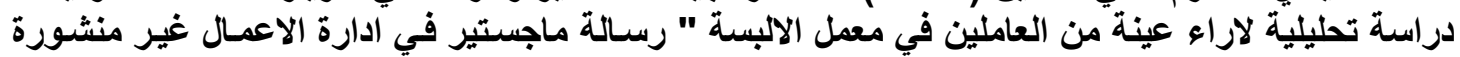

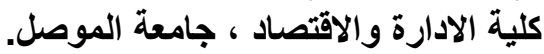

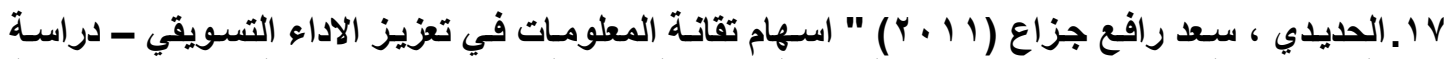

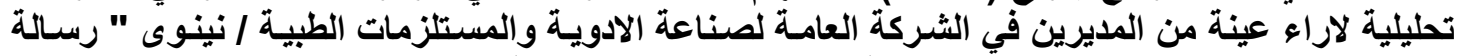

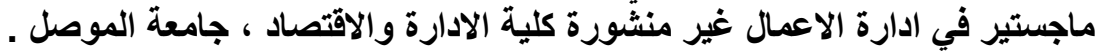

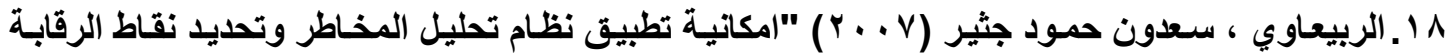

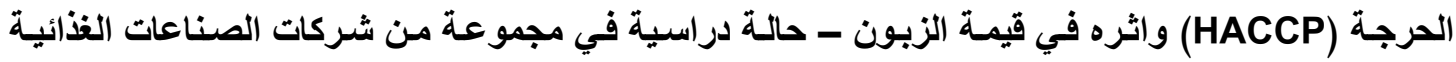

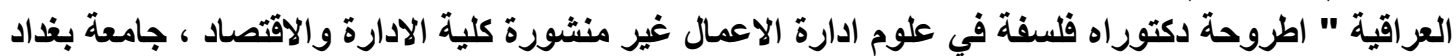

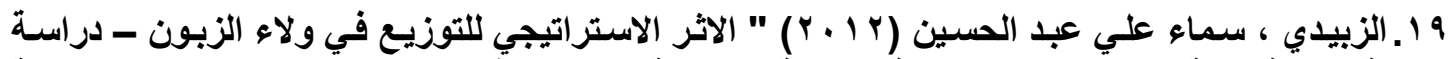

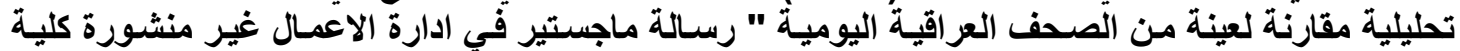

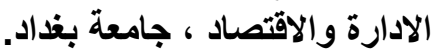

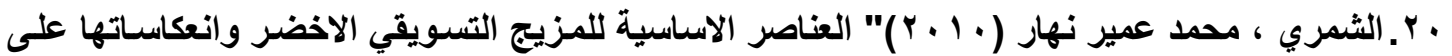

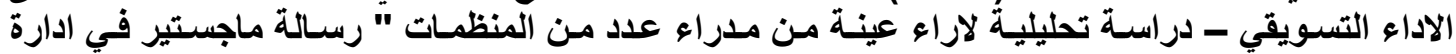

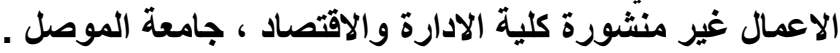

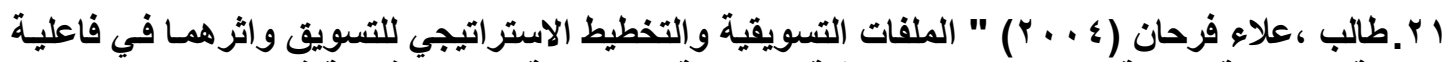

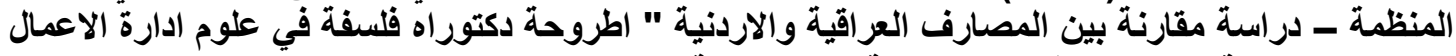

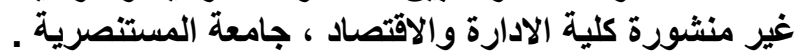

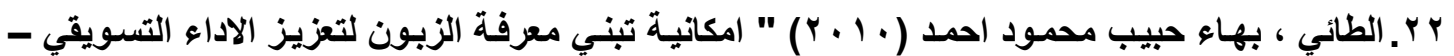

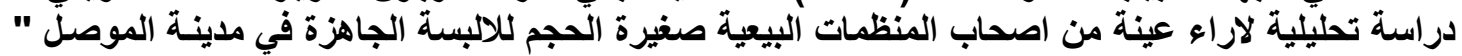

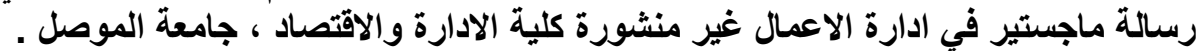

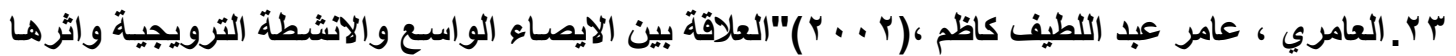

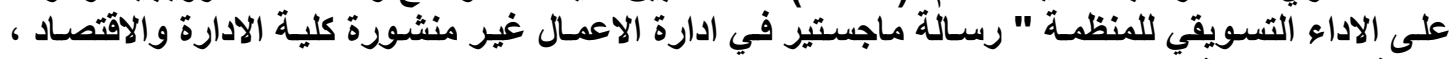

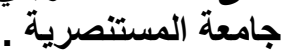

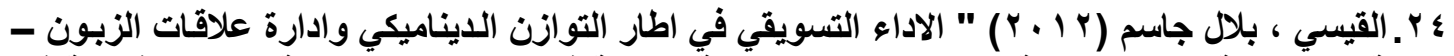

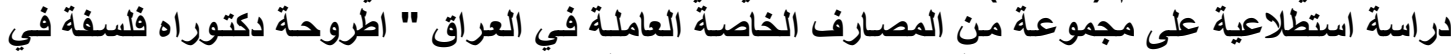

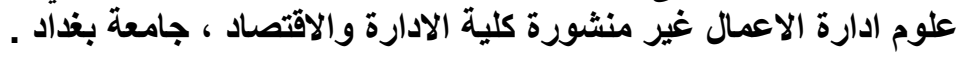

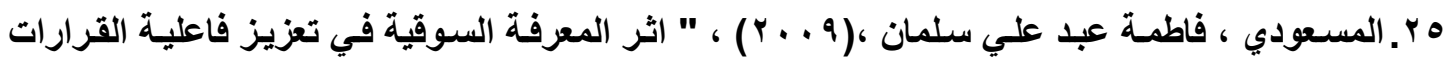

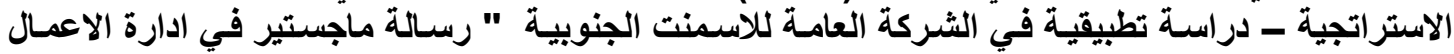
غير منشورة ،كلية الادارة والاقتصاد ،جامعة كربلاء.

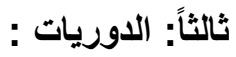




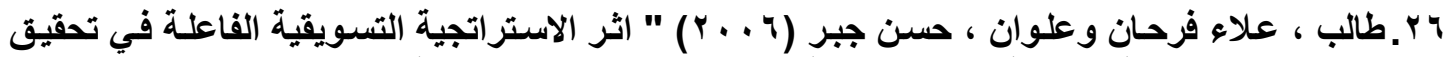

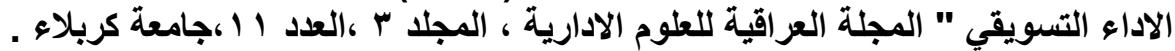

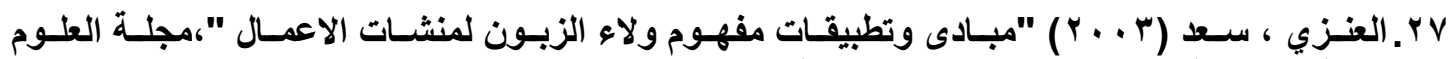

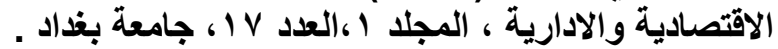

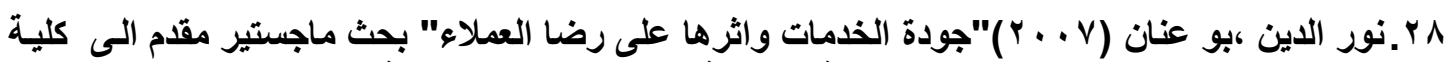
العلوم والاقتصاد وعلو التسييز والعلوم التجارية ، جامعة محمد بوضياف المسيلة ، عمان .

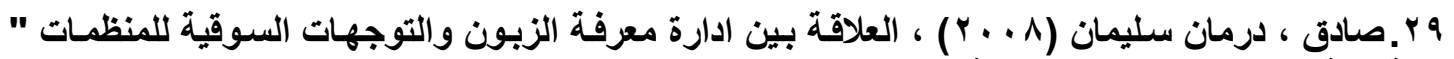

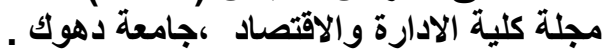

Fires BOOK:

1. Beech ,John \&Chadwick ,Simon ,(2007)," The Marketing of Sport "prentice Hall, New York .

2. C.S.Summers,Donna (2009),"Quality Management Greating and Sustaining Organizational Effectiveness "2th, Prentice - Hall, pearson Education International.

3. David ,F(2001)," Strategic Management :Concept \&Cases " 8 th ,Prentice Hall,Inc .

4. David,Bowie ,Francis Buttle(2004) "Hospitality Marketing an Introduction" $5^{\text {th }}$ Elsevier butterworth.

5. G.Gooper ,Lee \& Nakanishi ,Masao ,(2010),"Market-Share Analysis “ Kluwer Academic, Boston Dordrecht ,London .

6. Hollensen ,Svend ,(2011)," Global Marketing " ${ }^{\text {th }}$ pearson Education Limited.

7. Kimbrell ,Grady \& Woloszyk ,Carl A. (2006)," Marketing Essentials"The McGraw-Hill, New York

8. Kotler, Philip,et al (2010)"Marketing for Hospitality and Tourism "5th ,Prentice Education,.Lnc.New Jersey.

9. Korzenny,Felipe \& Korzenny, Betty ann ,(2012),"Hispanic Marketing" Elsevier Inc ,All rights reseved .

10. Kotler ,Philip ,\& Keller ,Kevinlane (2009),"Marketing Management “ $13^{\text {th }}$, pearson Education International .

11. Kotler, Philip,(2000)"Marketing manament "The Millennium Edition ,Prentice Hall.Lnc.

12. Kurowski ,Lech \&Sussman,David,(2011)," "Market Research “

13. M.Gryna ,Frank, et al ,(2007)"Jurans Qualty Planning and Analysis " ${ }^{\text {th }}$ Tata Mc Graw-Hill ,New York .

14. Mathur ,U.C. ,(2008),'Business to Business Marketing "New Age International.

15. Mcdaniel ,Carl ,Gates,Roger ,(2010)" Market Research" $8^{\text {th }}$, John Wiley \&Sons,lnc.

16. O.Bearden,William, et al (2007)," Marketing Principles and Perspectives " $15^{\text {th }}$,Mc Graw-Hill Lrwing New York .

17. Pride , William \& Ferrell o.c., (2000), "Marketing Concept and Strategies “11th ,Hougnton Mifflin Company Allrights resevved. 
18. Pride , William \& Ferrell o.c., (2003), "Marketing Concept and Strategies " $12^{\text {th }}$,Hougnton Mifflin Company Allrights resevved .

19. Stone ,BOB \& Jacobs , Ron (2008)," Successful Direct Marketing Methods"Mc Graw Hill, New York .

20. Jarvis , Jackie ,(2007), “ 85 Inspiring Ways to Market Your Small Business “ How to Book .

Second :Articles \&Researches:

1. A.Czepiel,John \& A.Kerin ,Roger ,(2012), “ Competitior Analysis” work pepar

2. .Alhawari ,Samer et al ,(2008)," The effects of Knowledge Process for Customer on the achievement of Customer Knowledge Retention "6 Communications of the IBIMA, Vo, 6

3. Bao,Yongchuan, et al ,(2012), "Net work - Based Market Knowledge and Product Innovativeness " Springer Science, Business Media .

4. Cooil ,Bruce ,et al (2007), "Alongitudinal analysis of Customer Satisfaction and Share of Wallet : Investigating the Moderating Effect of Customer Characteristic"Journal of Marketing, Vo 71.

5. Jammerngy,Michael,(1998),'Five Styles of Customer Knowledge Management and How Smant Companies use Them to Great Value",European Management Journal ,VO,20 NO,5.

6. Karami ,Azhdar, et al (2010), " customer knowledge management in the Iranian Banks :An Empirical research" Euro Journals, Inc.

7. Li , Tiger \& Calantone , Rogerj ,(1998), " The Impact of Market knowledge Competence on New Product Advantage :Conceptualization and Empirical Examination " Journal of Marketing, Vo 1, No 62 .

8. M.De Luca , Luigi \& Gima ,Kwaku Atuahene ,(2007)," Market Knowledge Dimensions and Cross-Functional Collaboration:Examining the Different Routes to Product Innovation Performance " January of Marketing Vo,71.

9. Pont ,Marcin \& Shaw, Robin (2003),"Measuring Marketing Performance :A Critique of Empirical Literature “ Deakin University .

10. Rowley, Jennifer, (2005), " Customer Knowledge management Or Customer Surveillance “,Global Business and Economies Review,VO 7,NO1. 
11. Roy,Tapan Kumer \& Stavropulos, Christos ,(2007), "Customer Knowledge management in the e- Business Environment " Lulea University of Technologg.

12. Sainy, Romi (2010)"A study of The Effect of Service Quality on Customer Loyalty in Retail Outlets "Ximib Journal of Management.

13. Smits, Armand ,et al (2011), " Research Paper Exploring Market Knowledge in Product Development of Chemical Firms " Journal of Business Chemistry

14. T.D,Sofianti ,et al ,(2010),"Customer Knowledge Co-craetion Process in New product Development " proceedings of the Word Congress on Engineering ,London,VO 1.

15. Te Tu,Yu ,et al (2011),"The Effect of Service Quality ,Customer Perceived Value and Satisfaction on Loyalty "Journal of Economics and Behavioral Studies, Vo, 3 No3.

16. Te Tu,Yu et al ,(2011),"The Effect of Service Quality,Customer Perceived Value And Satisfaction on Loyalty "Journal of Economics and Behavioral Studies VO, 3 NO,3.

17. Wang ,Yonggui \& Feng,Hui,(2012),"Customer Relationship Management Capabilities: Measurememnt, Antecedents and Consequences "Management Decision, Vo,50 Iss: 1

Third : Internet

1. Holetzky, Sherry,(2008), "What is Customer Loyalty", http://www. Wisegeeks. 


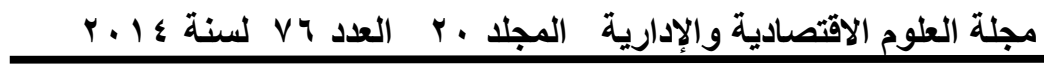

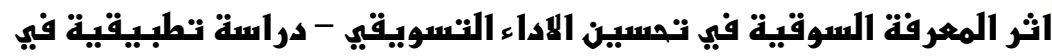

$$
\begin{aligned}
& \text { شركات الاتصال للهاتف المهمول في العراق }
\end{aligned}
$$

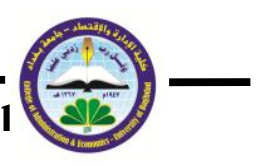

The impact of the market knowledge to improve marketing performance an empirical study for mobil communication companies in iraq

\section{ABSTRACT}

The study aimed to determine the extent of market knowledge in the companies researched, as if market knowledge is qualified to lead the companies researched to achieve marketing performance, for this purpose, formulated hypotheses of the study in three hypotheses, the first major hypothesis "there is a correlation with significance of market knowledge to improve the marketing performance, "while the second major hypothesis, "there is a significant moral influence of market knowledge to improve the marketing performance " these hypotheses targeting to determine the role played by market knowledge in the leadership of companies researched to achieve improvement in marketing performance .

And the study showed significant results for most stages of market knowledge to improving the marketing performance, as well as the study reached the existence of significant differences between the companies researched the level of market knowledge to improve the marketing performance, and led the results of the practical side of the study on a number of conclusions was the most prominent of which contribute to the market knowledge that makes the organization more able to achieve the improvement of the marketing performance and dominating the target markets, as well as the existence of significant differences between the two companies researched the level of market knowledge to improve the marketing performance .

Key words :market knowledge ,marketing performance. 